\title{
Franjo Tuđman i problemi objavljivanja knjige Nacionalno pitanje u suvremenoj Europi
}

\author{
MIRKO ĆOSIĆ \\ Zagreb, Hrvatska \\ mircosich@gmail.com
}

\begin{abstract}
Na temelju izvora iz fondova Hrvatskoga državnog arhiva, osobito dokumentacije koju je Služba državne sigurnosti Republičkog sekretarijata za unutrašnje poslove Socijalističke Republike Hrvatske prikupila o Bogdanu Radici i Franji Tuđmanu te korespondencije tih dvaju intelektualaca koju je ta služba nadzirala, autor u radu iznosi okolnosti inicijative tiskanja Tuđmanove knjige Nacionalno pitanje u suvremenoj Europi u inozemstvu. Naime, nakon kaznenih progona 1972. i 1981. Tuđman je prisilno udaljen iz društvenoga života, pritiješnjen stvarnošću jugounitarizma. Odvažni napor tiskanja knjige, usprkos svim prijetnjama, prerastao je u pokušaj njegova izlaska iz nametnute izolacije koja je trajala sve do 1988., kada je primljen u Društvo književnika Hrvatske, nakon čega počinje nastupati na javnim tribinama te 1989. objavljuje i knjigu Bespuća povijesne zbiljnosti.
\end{abstract}

Ključne riječi: Bogdan Radica; Franjo Tuđman; Služba državne sigurnosti; korespondencija; Nacionalno pitanje u suvremenoj Europi

\section{Uvod}

Namjera je ovoga rada pomoću dosad manje poznate arhivske građe koja je postala dostupna nakon stupanja na snagu Zakona o arhivskom gradivu i arhivima iz 2018., prije svega osobnih dosjea Službe državne sigurnosti (SDS) Franje Tuđmana i Bogdana Radice, te velike građe osobnoga arhiva Bogdana Radice osvijetliti okolnosti tiskanja važne knjige Franje Tuđmana Nacionalno pitanje u suvremenoj Europi. Naime, nakon kaznenih progona, političkih osuda i zatvorskih kazni (1972. i 1982.), uz zabranu javnoga istupanja u tisku, na 
radiju, televiziji i javnim skupovima, Tuđman dolazi pod permanentnu obradu policijskoga represivnog aparata te biva marginaliziran i stjeran u dugogodišnju izolaciju, koja je uz stanovita popuštanja trajala do 1989. i tiskanja Tuđmanove najpoznatije knjige Bespuća povijesne zbiljnosti. Važnost koju je Tuđman pridavao knjizi Nacionalno pitanje u suvremenoj Europi sagledava se iz želje artikuliranja znanstvenih teza vezanih za nacionalno pitanje u tadašnjoj Europi i Jugoslaviji, poglavito pitanja nacionalne suverenosti kao ključne odrednice za opstanak i razvoj svakoga naroda, držeći tadašnje stanje u Jugoslaviji neodrživim. Naravno da totalitarna komunistička vlast u Jugoslaviji, opterećena stalnim nacionalnim antagonizmima i dubokim krizama, nije mogla dopustiti tiskanje takvih teza, od kojih je ključna bila ona da višenacionalne državne zajednice nose trajnu opasnost od međunacionalnih, a time i međunarodnih konflikata. S druge pak strane Tuđmanova spremnost riskiranja vlastite egzistencije poradi angažmana u tiskanju knjige u inozemstvu, uz suradnju s „neprijateljskom emigracijom”, postaje dramatičan pokušaj njegova izlaska iz prisilne izolacije. Ovim se radom na temelju dosjea SDS-a i višegodišnje korespondencije koju je Tuđman vodio s više osoba u inozemstvu - poglavito Radicom, te citatima iz memoarskih zapisa i dnevnika tih dvaju intelektualaca na neki način pokušava rekonstruirati ideološki pritisak kojem su bili izloženi te pokazati sumorno društveno-političko ozračje umiruće Jugoslavije.

\section{Bogdan Radica kao glavni akter}

„U toku 1969. zapaženi su intenzivni kontakti Radice s Tuđman Franjom iz Zagreba." Tako počinje dio Radičina ${ }^{1}$ dosjea u kojem se navode informacije vezane za njihove kontakte. ${ }^{2}$ To je izvješće nastalo kad je Okružno javno tužilaštvo

\footnotetext{
1 Bogdan Radica, poznati politički emigrant, publicist, povjesničar i književnik, rođen je u Splitu 26. kolovoza 1904. godine. Nakon studija u Ljubljani i Firenci imenovan je 1928. dopisnikom Obzora iz Pariza, čime započinje njegova bogata novinarska karijera. Postaje izaslanik za tisak pri veleposlanstvu Kraljevine Jugoslavije u Ateni, a nakon proglašenja Banovine Hrvatske 1939. radi u državnom uredu za vanjski tisak u Beogradu. Drugi svjetski rat provodi u SAD-u, gdje je od 1941. radio u tiskovnom uredu Kraljevine Jugoslavije u New Yorku. Tijekom rata postupno se distancirao od izbjegličke vlade u Londonu te je 1943. započeo aktivnu promidžbu partizanskoga pokreta u zapadnom tisku. Nakon rata 1945. dolazi u Beograd u Ministarstvo informiranja, ali suočen sa stvarnošću totalitarnoga režima komunističke Jugoslavije, vraća se u SAD i postaje jedan od njezinih vodećih kritičara. Nakon posjeta Hrvatskoj početkom devedesetih, umire u New Yorku 1993. godine. Vidi u: „Radica, Bogdan”. Opširnije o Bogdanu Radici vidi u: Bogdan Radica, život i vrijeme. Zbornik radova s međunarodnog znanstvenog skupa održanog u Split 25. rujna 2017., ur. Ivan Bošković i Marko Trogrlić (Split: Književni krug, 2019).

2 Cijeli dokument sastoji se od pet stranica i vodi kao „Predmet: Radica Bogdan osoba s kojim je okrivljeni Tuđman dr Franjo održavao kontakt”. Dokument je datiran 19. travnja 1972., dakle tri mjeseca nakon što je Tuđman prvi put uhićen, a sastavio ga je Dmitar Šijan, djelatnik SDS-a, bivši prvak Jugoslavije u džudu i član zagrebačkoga džudaškoga kluba „HAŠK Mladost”. U dokumentu se nabrajaju „grijesi” Bogdana Radice, koji su uglavnom tipa „suradnja s ustaški orijentiranim emigrantima" - iako on sam nije ustaša, da bi se tako ocrnjen pokazao kao osoba s kojom Tuđman ima stalne veze, dakle Radičina krivnja je i Tuđmanov krimen. HR-HDA-1561- SDS RSUP SRH, Dosje
} 
Zagreb radi vođenja daljnjega kaznenog postupka protiv okrivljenoga Franje Tuđmana nalogom od SDS-a, Centar Zagreb zatražilo mnoštvo podataka, taksativno nabrojenih na dvije stranice. ${ }^{3}$ Očito je da je tužilaštvo započelo prikupljati podatke o okrivljenom Tuđmanu tek tri mjeseca nakon njegova uhićenja, što jasno pokazuje da je optužnica protiv njega izašla po nalogu Partije - najprije je uhićen, a tek su onda mjesecima traženi fabricirani dokazi. ${ }^{4}$ Takvi nekonzistentni i manipulacijski sudski postupci bili su redovita praksa tadašnjih organa progona, stvarajući na taj način kafkijansku atmosferu iracionalne krivnje i ozračje opće pravne nesigurnosti. ${ }^{5} \mathrm{U}$ navedenom izvješću poglavito se ističe Radičino djelovanje u promicanju i reklamiranju Tuđmanove knjige Velike ideje i mali narodi te da se posebno angažirao u organiziranju ponovnoga Tuđmanova dolaska u Sjedinjene Američke Države (SAD) nakon njegova prvoga dolaska 1966., kada je nekoliko mjeseci boravio na Harvardu, gdje je imao intenzivni kontakt s hrvatskim iseljenicima i predstavnicima hrvatske zajednice u SAD-u. Radica je tadašnjoj jugoslavenskoj vlasti bio posebno politički neugodan jer se radilo o vrhunskom

96681 (prekrižen i ispod napisano 319291) Bogdana Radice od 69 stranica. Inače, Šijanovo ime nalazi se na prvoj stranici Tuđmanova zatvorskoga dnevnika Petrinjska 18, kad nabraja osobe koje su ga došle uhititi: „Oko 5 sati probudila me Katica: ‘Gospodine, došli su milicija i civili, traže vas!' Izašla je. Što li misli?! Dakle, tu su. Jasno. Nakon svega što se zbivalo od 1. dec., osobito nakon članka Vlade Miletića u božićnom i novogodišnjem NIN-u. Zar ih nisam očekivao svaku noć?! Ogrnuo sam kućni kaput i našao ih u predsoblju, čitav odred - šestorica. Samo jedan u odori. Jedan me pita jesam li to ja. Kaže da mi je valjda jasno. Što? Imaju li nalog, nemaju, ali ispunit će ovdje na licu mjesta. Imaju na to pravo po zakonu. Zakon! Tražim da pokažu isprave: Nikola Komazec, no on nije glavni iako on piše nalog, glavni je onaj crni što vrlo sliči Bori Jovanoviću, on je Dmitar Šijan, ostali su Mile Malinović (od Gračaca), Graovac, Jovo Ajzenhauer (meni je rekao da je Ivo, kolega ga je zvao Jovo, a i na omotnici što mu jedan donese stoji Jovo) i Aleksić iz Grdelice kod Leskovca.” F. TUĐMAN, Petrinjska 18, 9.

3 Među ostalim, zatraženi su od SDS-a podaci o više osoba iz inozemstva, njihovoj djelatnosti, poglavito publikacijama, bilo djelima bilo člancima u emigrantskom tisku, s kojima je Tuđman održavao veze (Stanko Vujica, Bogdan Radica, Mate Meštrović, Stephan Vuglen, Mirko Lamer, Jere Jareb, Karlo Mirth). Također se nabrajaju publikacije i korespondencija koju je Tuđman vodio $s$ različitim osobama, pa tužilaštvo traži da se obavi razgovor s tim osobama u svezi s njihovim vezama s okrivljenim. Tako se navode Vinko Vučić, Ivan Gabelica, odvjetnik Vladimir Marić i Antun Kozina. Zatim je trebalo ispitati na koji način surađuju Tuđman i Zvonko Ivanković Vonta, Marijan Klepac i Zvonko Lisinski. MALETIĆ, Dr. Franjo Tuđman, Dopis Okružno javno tužilaštvo Zagreb, Broj: KT-40/72, Zagreb, 11. travnja 1972., 556-557.

4 „Ispitivanjima provedenim 17. i 24. travnja, te 4. i 16. svibnja 1972. godine do iznemoglosti je iscrpljivan dr. Tuđman jer je morao potanko obrazlagati zašto je napisao neki članak, zašto se susreo s Bogdanom Radicom i tomu slično." VUKOVIĆ, Dr. Franjo Tuđman u sudskim dosjeima, 20. Isti autor na više mjesta piše o sudstvu koje je tijekom dvaju suđenja okrivljenom Tuđmanu bilo u službi komunističke vlasti. Isto, 34, 35 i 53-55.

5 Pravni sustav u tadašnjoj Jugoslaviji bio je instrument u rukama Partije koji je služio ostvarenju, izgradnji i očuvanju jugoslavenskoga komunističkog sustava. Savezni i republički zakoni bili su političko-ideološki instrumentalizirani i kao takvi uporabljivani da bi Partija trajno imala neograničeni monopol nad društvom. Uz diktaturu proletarijata i socijalističko samoupravljanje, partijska instrumentalizacija prava bila je jedno od temeljnih načela toga sustava. Autonomija prava ili nekakva odvojenost političke i sudbene vlasti u praksi nije postojala. „Komunisti su zakon shvaćali kao sredstvo u rukama vladajuće klase koje služi za zaštitu i ostvarenje njezinih političkih i drugih interesa, a pravni je poredak bio samo formalni okvir djelovanja.” MIHALJEVIĆ, „Ustavna uređenja temeljnih prava u Hrvatskoj 1946. - 1974.”, 33. Opširnije o reintegraciji hrvatskoga pravnog poretka u socijalističkom pravnom krugu vidi u: GAVELLA, Građansko pravo. 
intelektualcu koji je prije obnašao niz istaknutih funkcija u diplomatskom koru Kraljevine Jugoslavije, a čak je i tijekom rata bio iskreni Jugoslaven, pa ga nisu mogli jednostavno etiketirati. Osobito im je bio nepoželjan njegov novinarski angažman jer je pisao na engleskom jeziku za New York Times, The Nation, The Free World i druge novine o naravi i teroru jugoslavenskih komunističkih vlasti. Osim toga njegova supruga Nina Ferrero, kći uglednoga talijanskog profesora Guglielma Ferrera, imala je jake veze s nekoliko američkih kongresnika, a to znači i stanovitu političku zaštitu, pa je jugoslavenskim službama bilo teško i nezgodno prići Radici i pokušati ga neutralizirati. Ipak, prema prokušanom receptu, i on je bio označen kao pripadnik ekstremne emigracije i SDS ga je smatrao opasnim za režim te je nad njim godinama vršena operativna obrada $(\mathrm{OO})^{6}$, što će biti uporabljeno u Tuđmanovu političkom progonu. ${ }^{7}$

Inače je SDS počeo aktivno pratiti Tuđmana 1967., međutim, za razliku od drugih dosjea, u njegovu ne nalazimo razloge zbog kojih je započela obrada nad njim. Na samom početku dosjea Franje Tuđmana stoji da je nakon boravka u SAD-u i povratka uspostavio kontakt s političkim emigrantima, gdje je poglavito istaknut Bogdan Radica. Njega u tom dosjeu SDS opisuje kao poznatoga emigranta koji je povezan s grupom emigranata u SAD-u i Europi, a prema navodima iz dosjea i s američkom obavještajnom službom. ${ }^{8}$ Nadalje, u dosjeu stoji da se u brojnim kontaktima tijekom boravka u SAD-u Tuđman isticao „antisrpskim stavovima” i izjavama da će oni (komunisti) uspjeti ono što nisu uspjeli ni Vladko Maček ni ustaše, a to je oslobođenje Hrvatske od Srbije. ${ }^{9}$ U tom razdoblju Tuđman uspostavlja kontakt i s više osoba iz Hrvatske akademije Amerike, osobito s Matom Meštrovićem, Antom Kadićem i drugima. Kao svojevrsni posrednik između

\footnotetext{
6 Služba državne sigurnosti u radu je koristila specifičnu terminologiju rabeći brojne akronime. Tako OO (operativna obrada) podrazumijeva da se ta osoba smatra „državnim neprijateljem” i da se nalazi pod stalnom obradom. Prije toga postoje različite faze procjene nečije neprijateljske djelatnosti, od kojih je najčešći akronim za početni oblik nadzora POO (prethodna operativna obrada). Postoji i OK (operativna kontrola), što se koristilo nakon OO-a, kad se sumnjalo da bi prethodno praćena osoba ponovno mogla neprijateljski djelovati.

Pojedini dokumenti potjecali su iz skupnih operativnih akcija koje je SDS primjenjivao na odabrane skupine koje bi dobivale svoje kodno ime. Tako iz skupne operacije kodnoga naziva „Astra” imamo podatke o Radičinim ambicijama o vodećoj ulozi u emigrantskim krugovima i zbog njegovih financijskih mogućnosti. Međutim, ono što je istaknuto političke su veze. „Novi podaci ukazuju takodjer da je Radica u dobrim odnosima s ličnim Nixonovim savjetnikom Kisingerom sa kojim je stari prijatelj, te se sa njime navodno redovno razgovora i savjetuje o Jugoslaviji, Istočnoj Evropi i Evropi uopće.” HR-HDA-1561-SDS RSUP SRH, Centar Zagreb, 24. veljače 1971., informacija br. 60, Predmet: Zbirni prikaz o aktivnosti jednog broja lica obuhvaćenih grupnom obradom „Astra”.

8 MALETIĆ, Dr. Franjo Tuđ̇man, 2. U Tuđmanovu dosjeu SDS-a Radica se spominje 54 puta, a kasnije optužnice podignute $u$ dva navrata protiv Tuđmana bile su samo kompilacija podataka izvađenih iz dosjea.

9 Isto, 3.
} 
tih osoba i Tuđmana spominje se Mirko Lamer ${ }^{10}$ iz Rima, poglavito u kontaktima s Radicom i Antom Smithom Pavelićem iz Pariza. Također se navodi da je upravo Lamer dogovorio susret Radice i Tuđmana koji se dogodio u Firenci početkom kolovoza 1969. godine. S tim se u vezu dovodi i angažman Radice u propagiranju Tuđmanovih ideja i knjiga preko emigrantskih tiskovina i traženju mogućnosti za Tuđmanov dolazak u SAD u svojstvu stipendista ili predavača na nekom od američkih sveučilišta. Radica je pritom još isticao da bi svatko kome je u srcu Hrvatska morao biti upoznat s Tuđmanovim stavovima i idejama. Štoviše, Radica naglašava da Tuđman spada u nositelje „hrvatskog preporoda”, čiji napisi upozoravaju na krizu u socijalističkoj Jugoslaviji, u kojoj hegemonizam guši sve njezine narode. Tuđman je osobno upoznao Radicu, prema kazivanju njegove supruge Ankice Tuđman, ${ }^{11}$ tijekom međunarodnoga seminara na Harvardu 1966., gdje je održao predavanje pod nazivom „The Future of Supremacy and of Coexistence in the Nuclear Age of the World's History". ${ }^{22}$ Tu je Radica saznao da Tuđman priprema novu knjigu, što je kod njega izazvalo osobitu pozornost. Radilo se o spisima za knjigu Nacionalno pitanje u suvremenoj Europi $i^{13}$ i Radica je s oduševljenjem ponudio pomoć u prijevodu na engleski i tiskanju knjige u SAD-u.

Tako zapravo počinje njihov kontakt i prijateljstvo koje će se s većim ili manjim intenzitetom nastaviti sve do Radičina posjeta Hrvatskoj u srpnju 1990., kada su se ponovno sreli, toga puta u novim okolnostima jer je Tuđman 30. svibnja 1990. u Saboru izabran za predsjednika Predsjedništva tada još Socijalističke Republike Hrvatske. Naravno, sve te činjenice iskoristili su djelatnici SDS-a koji su u svojim izvješćima uoči samoga Tuđmanova uhićenja i suđenja minuciozno prikupili podatke o svim njihovim kontaktima i sastanku u Firenci, koji su posebno

10 „U kontaktima s Tudjmanom zapažen je naglašen interes Lamer Mirka za zbivanja u zemlji. Neposredno nakon boravka u Zagrebu, Lamer je putovao u SAD i tamo uspostavljao vezu s Radica Bogdanom, Matom Meštrovićem i drugima. Izmedju ostalog u razgovorima s Tudjmanom, Lamer upoznava Tudjmana i o boravku Pavelić-Smith Ante u SAD, iz čega se može zaključiti da je Tudjman u direktnoj vezi s Pavelićem.” Isto, 32. Lamer je 1933. doktorirao ekonomiju u Leipzigu, a nakon proglašenja Nezavisne Države Hrvatske tajnik je u Ministarstvu za obrt, veleobrt i trgovinu. Ne slažući se s politikom Nezavisne Države Hrvatske, 1942. odlazi u Švicarsku, a nakon završetka rata 1945. u SAD, gdje je predavač na Howardovu sveučilištu. Ponovo se vraća u Europu kao voditelj odjela Organizacije za hranu i poljoprivredu Ujedinjenih naroda (FAO) u Rimu, gdje radi do umirovljenja 1972. godine. Opširnije u: KULIŠ, TKALČEVIĆ, „Lamer, Mirko”.

11 A. TUĐMAN, Moj život s Francekom. U knjizi je jedno kraće poglavlje naziva „Na tajnom zadatku" posvećeno Bogdanu Radici (str. 217-220).

12 Taj je članak, uz veliki broj drugih materijala, oduzet Tuđmanu pri njegovu uhićenja i vodio se pod rednim brojem 147., gdje se opisuje: „Primjerak na engleskom jeziku pisanog separata 'Budućnost nadmoći i koegzistencija u nuklearnom periodu svjetske historije.” Nastavlja se da je s tim člankom Tuđman sudjelovao u diskusiji 16. kolovoza 1966. na Harvardovu međunarodnom seminaru. MALETIĆ, Dr. Franjo Tudman, 391.

13 Knjiga dr. Franje Tuđmana Nacionalno pitanje u suvremenoj Europi objavljena je na engleskom (New York, 1981.), a potom na hrvatskom (München; Barcelona, 1981.) i njemačkom (Lidingö, Švedska, 1982.) te ponovo na hrvatskom (Zagreb, 1990.). 
negativno tematizirali u svojim ocjenama, sagledavajući ga u krajnje negativnom kontekstu. Zato je, nakon što je Tuđman prvi put uhićen 1972., ključni krimen bila njegova veza s „ekstremnom emigracijom”, o čemu svjedoči pismo od 22. listopada 1975. koje je Tuđmanov bliski suradnik Bruno Bušić poslao Radici nakon što je emigrirao u London. Naime, nakon zajedničkoga suđenja 1972. i izdržavanja zatvorske kazne Bruno Bušić emigrira na Zapad, i to - prema njegovu svjedočenju - zbog neprestanoga maltretiranja milicije i prijetnji. On iz Londona piše Radici da ga puno pozdravlja njegov prijatelj Tuđman, ali mu savjetuje da o tome nikome ne govori jer je Tuđman ostao u Jugoslaviji. Bušić kaže da je tijekom njihova suđenja često spominjano Radičino ime te se čitala njihova obimna korespondencija. Također su citirani Radičini istupi na „Hrvatskim razgovorima o slobodi”, pa Bušić s „ogorčenim sarkazmom” kaže da su na suđenju to bili „prvorazredni dokazi o Tuđmanovoj urotničkoj djelatnosti. Sve je to bilo lakrdija nad lakrdijama” ${ }^{14}$ Bušić je također pretpostavljao da će Tuđman ponovno u zatvor i da je to naznaka za drugo Karađorđevo, koje bi moglo biti gore od prvoga jer su zatvori opet prepuni političkih zatvorenika. Za sebe govori da je dosta propatio i da je na rubu snaga, ali da su i zatvori lakši od osobnih razočaranja, misleći na ljude. Posebno mu je neshvatliivo kako dio emigracije nesvjesno radi za Jugoslaviju i podržava njezine zakulisne igre, spominjući kao primjer Juru Petričevića, koji godinama širi famu o skorašnjem ulasku Jugoslavije u blok komunističkih država predvođenih Sovjetskim Savezom. To Bušić smatra besmislicama jer jugoslavenski predsjednik Josip Broz Tito zna da bi time on prvi „ostao bez glave”, a pogotovo ne bi mogao na međunarodnoj sceni glumatati nekoga „velikog meštra”. Osim toga tim pričama širi se neutemeljeni strah od Sovjeta, koji jugoslavenska politika vješto koristi u dobivanju kredita od Zapada te vojne i policijske pomoći. ${ }^{15} \mathrm{Uz}$ neizostavno etiketiranje kao pripadnika ekstremne emigracije, Radičin glavni krimen bio je u njegovim tekstovima na engleskom u kojima su se tematizirale društvene i političke okolnosti u komunističkoj Jugoslaviji. Usto je bio istaknut kao „nosilac ideja o povezivanju emigrantskih krugova iz SAD i istaknutih emigranata u Europi [...]”. Njegov članak u emigrantskom tjedniku Hrvatski glas, u kojem je promovirao Tuđmanovu knjigu Velike ideje i mali narodi, prema spisima SDS-a, izazvao je veliku pozornost i interes u iseljeničkim zajednicama, što je rezultiralo dobrom prodajom knjige i željom da se upozna njezina autora. ${ }^{16}$

\footnotetext{
14 Pismo Brune Bušića za Bogdana Radicu iz Londona od 22. listopada 1975. HR-HDA-1769-Radica Bogdan, kut. 24, bijela košuljica 245.

15 Isto. Pismo završava Bušićevim razočaranjem Rudijem Supekom, koji na skupovima ističe da on govori jugoslavenskim jezikom i promiče prava afričkih naroda, a o neslobodi svojega naroda ni riječi. Pismo je otipkano pisaćim strojem, a završava rukom dopisanim dodatkom u kojem Bušić izvješćuje Radicu da će mu uskoro poslati opis svojih gorkih iskustava iz zatvora u Staroj Gradiški.
}

16 MALETIĆ, Dr. Franjo Tudman, 15-16. 
„Razgovor s Bogdanom Radicom o njegovim kontaktima s Franjom Tuđmanom, Budišom i Čičkom u Italiji ljeta 1971.”

U izvješću „Razgovor s Bogdanom Radicom o njegovim kontaktima s Franjom Tuđmanom, Budišom i Čičkom u Italiji ljeta 1971. ${ }^{\prime 17}$ suradnik konspirativnoga imena „Rade" ${ }^{\text {"18 }}$ detaljno opisuje razgovore koje je vodio s Bogdanom Radicom tijekom svojega posjeta SAD-u krajem 1971. godine. ${ }^{19}$ Opis njihova druženja i tema o kojima su razgovarali ostavlja dojam da su se poznavali otprije. Tako „Rade” kaže da je već drugoga dana boravka u New Yorku bio pozvan $\mathrm{k}$ Radici na ručak. Radica je na početku izrazio razočaranje jugoslavenskim disidentom Milovanom Đilasom, s kojim je imao više susreta u New Yorku te mu je ovaj otvoreno iskazivao svoje jugoslavenstvo. Inače, Radica ga je podržavao i afirmativno pisao o njemu držeći da je to pukotina koja će na kraju dovesti do pucanja jugoslavenskoga političkog jednoumlja. Radica također spominje da je Đilas njegovu prijatelju, hrvatskom političkom aktivistu u SAD-u Mati Meštroviću, čak rekao da hrvatsku oporbu treba ugušiti tenkovima, pokazujući i time da je na velikosrpskim stajalištima. ${ }^{20} \mathrm{U}$ nastavku izvješća još se navodilo da je Radica detaljno opisao kako je u svoju vilu kod Firence primio u goste Franju Tuđmana i vođe studentske pobune u Hrvatskoj iz 1971. Dražena Budišu i Ivana Zvonimira Čička, ne precizirajući jesu li bili zajedno. Radica je izvoru rekao da su svi bili optimistični glede tadašnje situacije u Hrvatskoj, vjerujući da su započete promjene u Hrvatskoj trajne. Radica se ukratko osvrnuo i na njihove osobnosti, donoseći prosudbu o svakome od njih. Za Budišu je rekao da je „veoma pametan, ambiciozan, ali politički amater". Drži da je Budiša komunist koji želi ostvariti slobodu za Hrvatsku pod vodstvom Savke Dabčević-Kučar i Mike Tripala, ali u granicama Jugoslavije. Čička je procijenio kao „histerika-klerikalca i anarhistički raspoloženog", a o Tuđmanu se izrazio prilično ambivalentno u smislu da ga cijeni kao povjesničara, „ali ga smeta njegova bolesna ambicija. Želi da bude u svemu prvi”. ${ }^{21}$ Treba napomenuti da je Budiša opovrgnuo da se u Italiji sastao s Radicom, upozoravajući da istupa u javnosti kako udbaške izmišljotine

\footnotetext{
17 Isto, 185. Tako je naslovljen strojno otipkan dokument u čijem je desnom kutu olovkom dopisano Rade (suradnik službe), a ispod toga J. Jakovljević (agent službe koji ga je držao na vezi), bez datuma.

18 Josip Manolić u svojim sjećanjima opširno piše o tom suradniku, otkrivajući njegov identitet. Bio je to agronom Franjo Gaži, „političar, prevoditelj, obavještajac i suradnik stranih obavještajnih službi". Ustvrdio je da je bio jedan od najdragocjenijih suradnika SDS-a RSUP-a. Vidi: MANOLIĆ, Špijuni i domovina, 54-59.

19 DB Zagreb, 31. siječnja 1971. Zagreb. Suradnik „Rade” boravio je u SAD-u od 23. studenog do 31. prosinca 1971. Nakon povratka podnio je više izvješća, među ostalim i o susretima s Radicom. HR-HDA-1561-SDS RSUP SRH, Dosje Bogdana Radice, 26-27.

20 MALETIĆ, Dr. Franjo Tudman, 185.

21 Isto.
} 
ne bi postale neprijeporne povijesne činjenice. ${ }^{22}$ Radica je - slično kao i Budiši, nastavlja suradnik „Rade” - Tuđmanu zamjerao njegovu komunističku percepciju politike. Tuđman je tada predlagao Radici da mu pokuša osigurati dolazak u SAD u svojstvu predavača ${ }^{23}$, ali je Radica mislio da je Tuđman nepoznat i još s reputacijom komunista, što može biti itekako negativna karakteristika s obzirom na percepciju američke javnosti, pa u tom kontekstu spominje Milovana Đilasa, koji je svojim dolaskom u SAD izazvao pravu senzaciju. Jamačno nije slučajno što se Radica poziva na Đilasa u trenutku kad govori o trojici poznatijih disidenata iz Hrvatske, imajući na umu od njih stvoriti „hrvatskoga Đilasa” i na taj način promovirati hrvatsko pitanje u međunarodnoj zajednici. Međutim, i Radica je svjestan da su trenutačno u Jugoslaviji drukčiji kriteriji: „Dok se u Beogradu uklanjaju osobe zbog tobožnjeg liberalizma, u Zagrebu su Tuđman, [Marko] Veselica, [Zlatko] Tomičić, [Vlado] Gotovac optuženi za nacionalizam ustaškog tipa”, piše Tuđman 1975. u svojem dnevniku citirajući Radičin tekst iz Hrvatske revije u kojem Radica pokušava čitateljima u emigraciji predočiti kako se u Hrvatskoj brutalno guši svaki glas ili kritika, za razliku od Srbije, gdje je sasvim drukčija klima, ali sudbina Hrvatske ipak će se rješavati u domovini. ${ }^{24}$ Interesantno je na tu i slične teme pročitati desetke pisama koje je Radica razmjenjivao sa stanovitim odvjetnikom Arnirom, koji ga oslovljava s „dragi zemljače” u smislu splitskoga miljea. On 28. travnja 1979. odgovara na Radičino pismo pitajući se zbog čega Radica inzistira na tome da mu se pošalje čovjek od formata iz $\mathrm{Hr}$ vatske. ${ }^{25}$ Iz podužega odgovora daje se naslutiti da je dobro upoznat sa stanjem emigracije u smislu njihovih antagonizama, razjedinjenosti i utjecaja „Udbinih agenata”. Iako se vjerojatno radi o pseudonimu, zanimljivo bi bilo vidjeti tko se krije iza toga imena jer u pismima ostavlja dojam promišljenoga čovjeka koji je upućen u zbivanja u Jugoslaviji i zakulisne igre u partijskom vrhu. I Mirko Lamer 20. veljače 1978. u svojem se odgovoru na Radičino pismo pita: „Zašto Tudjman niječe da bi mogao igrati ulogu Đilasa?"26 Očito je Radičino uvjerenje da bi za promoviranje hrvatskoga pitanja u svijetu nužno bilo imati i jednoga hrvatskog disidenta proizašlog iz komunističkoga miljea.

\footnotetext{
22 „Dražen Budiša: Nisam se susreo s B. Radicom”, Večernji list (Zagreb), 17. 1. 2018., 20.

23 U pismu od 7. ožujka 1969. Sidneyu Hooku, istaknutom američkom filozofu i profesoru na Sveučilištu New York, Tuđman se poziva na Radicu informirajući profesora Hooka da se sprema izdati knjigu za koju bi mu dobro došao boravak na američkom sveučilištu tijekom jedne akademske godine. HR-HDA-1769-Radica Bogdan, kut. 58, bijela košuljica 624.

24 „Ključ našeg pitanja je kod kuće i u samoj zemlji... Nemoguće je Hrvatu zamisliti da se među hrvatskim komunistima nije našao jedan Đilas ili čak ni jedan Mihajlov... nitko tko bi vanjskom svijetu kazao istinu.” F. TUĐMAN, Osobni dnevnik, knj. I (1973. - 1978.), 181.

25 „Osoba za koju pitate /Šime Đ./ je u svakom slučaju neprikladna. Ovo mi je reklo više osoba kojima sam dao čitati vaše pismo.” Pismo Arnira (jamačno pseudonim), 28. travnja 1979. HR-HDA-1769-Radica Bogdan, kut. 60, bijela košuljica 649.

26 Pismo Mirka Lamera, 20. veljače 1978. iz Georgetowna (Gvajana). HR-HDA-1769-Radica Bogdan, kut. 61, bijela košuljica 663 .
} 
Suradnja domovinske i iseljene Hrvatske kroz Tuđmanovu i Radičinu inicijativu

Desetak godina nakon toga susreta kraj Firence, Tuđman 14. ožujka 1978. piše Radici emotivno pismo u kojem donosi reminiscenciju minuloga desetljeća, prisjećajući se prije svega njihova gostoljubiva susreta u Radičinu domu i prekrasna krajolika u L'Ulivellu. Tuđman u pismu izražava čuđenje time što se sve dogodilo i što je sve protutnjalo preko njegove glave u tih deset godina od njihova susreta. U isto vrijeme i hrvatski narod doživio je „svoje preporodno proljeće, i preživio ledene zimske mrazeve...”. ${ }^{27}$ Tuđman također izražava uvjerenje da će usprkos svemu hrvatski narod opstati i ostvariti svoje čežnje, ali više po žrtvama nego po nekom blagostanju. S druge je pak strane zanimljivo da nije optimist glede osobne sudbine, ali drži da je to ipak nebitno u odnosu na sudbinu Hrvatske, „a osobni pesimizam: po svemu sudeći prvi sam na listama zatora tamnih sila, što će ga mnogi od nas teško moći izbjeći...” ${ }^{28}$ Na kraju pisma - koje ovdje detaljnije citiram jer se već nazire formirani i svjesni domoljub i budući vođa hrvatskoga naroda koji se usudio njegovu tragičnu povijest uzeti u svoje ruke - Tuđman sjetno konstatira da su njegove reminiscencije završile u lamentacijama. Ipak, završna rečenica u pismu daje naslutiti kakvu je krizu Tuđman prolazio tih godina, kad kaže da osjeća unutarnji poticaj to napisati da bi ostalo svjedočanstvo za povijest ako se dogodi da on sam to jednom ne mogne reći ili ako o tome ne bi mogli govoriti ni njegovi rukopisi. ${ }^{29}$ Upravo negdje u to vrijeme, početkom veljače 1978., na švedskoj televiziji prikazana je emisija „Hrvati, borci za slobodu ili teroristi”, koja je podignula „veliku prašinu” u Jugoslaviji, pa je o tome počela medijska haranga. Tako Vjesnik od 18. ožujka 1978. donosi u nastavcima na dvije stranice tekst o toj emisiji, spominjući novinara Bengta Göranssona, Čička i Laurencea H. Silbermana te Gotovca i Tuđmana, uz posebni dodatak cjelovitoga teksta članaka 100., 118. i 119. Krivičnoga zakona Socijalističke Federativne Republike

\footnotetext{
27 Pismo Franje Tuđmana od 14. ožujka 1978. za Bogdana Radicu. HR-HDA-1769-Radica Bogdan, kut. 24, bijela košuljica 245. Dalje u pismu Tuđman se poetski izražava pri opisivanju sloma „hrvatskoga proljeća”: „Pogrom što je uslijedio razbješnjelom olujom, grozomornim udarima tuče i dugotrajnom mrazovitom smrzavicom polomio je, doduše, tek iznikle mladice i nabreknute pupoljke, satrvši i žetvu zrelog klasja i toliko žudjenog slobodnog daha, ali tla uništiti nije mogao [...], usprkos svemu korovu i svim nepogodama... i svim pomutnjama... Ništa nije bilo uzalud, a ne treba sumnjati da će poslije grozovitih, sušnih i hladnih godina - biti opet i novih proljeća, pa i plodorodnih ljeta. Nikada dosad, pa makar kako bili teški dani zatočeništtva u otudjenoj domovini, ili progonstva u zlosretnoj tudjini - muževi od značaja, uma i srca - nisu gubili nade, pa zašto bi sada!! Unatoč svemu - usprkos svim silama zatornim [...] optimista sam što se tiče sudbe hrvatskog naroda i u ovom povijesnom hipu! Isto to, na žalost, ne bih mogao reći za svoju osobnu kob..."

28 Pismo Franje Tuđmana od 14. ožujka 1978. za Bogdana Radicu. HR-HDA-1769-Radica Bogdan, kut. 24, bijela košuljica 245 .

29 Isto.
} 
Jugoslavije (SFRJ) kao smjernice za čitatelje gdje će stvar završiti. Posljednji tekst koji se bavi emisijom objavljen je 25. ožujka u Vjesniku pod sugestivnim naslovom „Sprega ustaških terorista i nacionalističkih korifeja”, iznad kojega je fotografija Tuđmanove kuće u Nazorovoj ulici u Zagrebu, i s popratnim tekstom: „U dijelu ove vile u zagrebačkom Tuškancu u kojoj se nalazi golemi Tuđmanov stan, Göransson je snimio dio svoje antijugoslavenske emisije."30

Potrebno je na neki način pokazati kakva je psihoza stvarana oko Tuđmana da bismo mogli vidjeti metode koje je koristio jugoslavenski režim, a to je bio permanentni teror, uključujući zastrašivanja, maltretiranja, prijetnje i poniženja. Razorne i pogubne posljedice takvih poigravanja s pojedincima i skupinama ljudi bile su svakodnevne. Tadašnja represija imala je krajnje negativan učinak na cjelokupnu hrvatsku stvarnost, kad više intelektualaca i sveučilišnih profesora poput Šime Đodana, Marka Veselice, Vlatka Pavletića, Petra Šegedina, Franje Tuđmana, Vlade Gotovca i drugih podvrgnete stalnim prozivkama i etiketiranjima u sredstvima javnoga priopćavanja, kad ih pozivaju na ispitivanja, vrše pritiske za denunciranje kolega i prijatelja te ih na kraju izvode na sud i javno blate dugi niz godina. Takva fizička, psihička, socijalna i druga maltretiranja imala su jedan temeljni cilj: spriječiti tematiziranje zbiljskih odnosa i stvarnih problema u SFRJ. Umjesto toga trebalo je organizirati diskusiju o nametnutim temama, primjerice o unutarnjem neprijatelju, lažnim uspjesima jugoslavenske privrede, Titovim sposobnostima vođe, jasenovačkim žrtvama i sl., koje su skrivale prave probleme svakidašnjega života. Tih mjeseci čitamo u Tuđmanovim zapisima da su se dan za danom ponavljale te uhodane sheme: negativni i prijeteći napisi u tisku i na televiziji, telefonske prijetnje, ${ }^{31}$ svakodnevni posjeti tobožnjih prijatelja koji su dolazili s najnovijim informacijama tipa "na spisku si za hapšenje” ili sumnjivim savjetima „zar ćeš čekati mirno da te odvedu”. Tuđman na Uskrs 1978., nakon još jedne teške noći uznemirenosti, bdijenja, promišljanja, dolazi pred dilemu što može napraviti ako se milicajci pojave na vratima i dođu po njega. „Postavlja mi se, naime, pitanje da li prekratiti ovu moju neizvjesnost odlaskom van?! Najnovije vijesti: pripremili su ne samo spiskove nego i logore na otocima." ${ }^{32} \mathrm{U}$ takvim okolnostima Tuđman ipak ne odustaje od svojih uvjerenja. Odgovarajući na Radičine upite iz njegova pisma od 7. travnja 1978. vezane za Tuđmanov rukopis na koji je Radica naišao u knjižnici Hooverova instituta pri Sveučilištu u Stanfordu,

\footnotetext{
$30 \quad$ F. TUĐMAN, Osobni dnevnik, knj. I (1973. - 1978.), 395.

31 „Slušaj ti, majku ti tvoju, izdajica, što ti sereš tamo na švedskoj televiziji’... Jučer je netko sličnu besjedu sasuo Ankici, pošto je rekla da me ne može zvati! Po načinu govora bio je to vjerojatno neki Banijac. Očito onako montirani članci u 'Vjesniku', s onakvim komentarima i slikama, značili su sami po sebi poziv četničkim elementima na pogrom (eto vam i kuće gdje taj stanuje!), a možda i sami iz centra organiziraju te pozive radi stvaranja pogromaške psihoze... Premda sam znao i znam da mogu očekivati i gore, pa i najgore stvari, ipak me to ne ostavlja mirnim.” Isto, 396, 397.

32 Isto, 396.
} 
naziva „Uzroci krize u monarhističkoj Jugoslaviji od ujedinjenja 1918. do sloma 1941.”, Tuđman odgovara da se radi o tekstu njegove doktorske disertacije. Ona je već bila u tisku 1966., ali je njezino tiskanje obustavljeno naredbom iz partijskoga vrha. ${ }^{33}$ Naime, Radica u pismu opisuje situaciju kad je naišao na Tuđmanov rukopis doktorske disertacije, ali drugoga dijela nije bilo. Vjerojatno ju je netko otuđio, možda i zbog prebogate bibliografije koju sadržava jer je rukopis najbolja analiza o tom razdoblju, pa Radica drži da bi trebalo pristupiti prijevodu i tiskanju knjige na engleskom. ${ }^{34}$ Tuđman mu zato u odgovoru iznosi tumačenje zbog čega nije još tiskana njegova disertacija služeći se alegorijskim slikama jer je „umjetnička slika pokojne starice” (aludira na Kraljevinu Jugoslaviju, op. a.) „bila odveć (fotografski) vjerna i nalik na svoju mladju sestru” (SFRJ, op. a.), „pa nije bilo zgodno dozivati u svijest ni uzrok njezine bolesti ni njezinu kob.... ${ }^{35}$ Usto je Radica u pismu napomenuo da je u razmišljanjima o potrebi tiskanja te knjige dobio informaciju da Tuđman upravo završava novu knjigu, Nacionalno pitanje u suvremenoj Europi. Pritom je zaključio da je ta tema kudikamo aktualnija i zanimljivija za međunarodnu javnost, koja o tome ne zna gotovo ništa. Zato Radica potiče Tuđmana neka mu što prije dostavi rukopise jer on drži da će uspjeti naći prevoditelja i nakladnika za tu aktualnu temu. ${ }^{36} \mathrm{U}$ svojem pismu Tuđman se referirao i na Radičin osvrt na rukopis „Nacionalno pitanje u suvremenoj Europi”. Rukopis je trebao biti gotov do lipnja i Tuđman počinje razmatrati mogućnost njegova dostavljanja Radici. Zato moli Radicu neka mu javi kada misli doputovati u Firencu da bi mogli uskladiti jednu „operaciju”. Osvrćući se na Radičinu sugestiju iz pisma da bi to nacionalno pitanje trebao obraditi iz marksističke vizure, Tuđman promišlja kako je i u knjizi Velike ideje i mali narodi pokušao izaći iz ideološkoga pragmatizma, ali ne i porušiti „sve mostove sa stvarnošću, u kojoj mi je bilo živjeti” ${ }^{37}$ No Tuđman ništa ne piše o Radičinu promišljanju, koji biranim riječima opisuje koliko ga je duboko dirnuo Tuđmanov slučaj, misleći na njegov

\footnotetext{
33 Pismo Franje Tuđmana od 2. svibnja 1978. za Bogdana Radicu. HR-HDA-1769-Radica Bogdan, kut. 24, bijela košuljica 245.

34 Pismo Bogdana Radice iz New Yorka za Franju Tuđmana od 7. travnja 1978. HR-HDA-1769-Radica Bogdan, kut. 20, bijela košuljica 170.

35 Pismo Franje Tuđmana od 2. svibnja 1978. za Bogdana Radicu. HR-HDA-1769-Radica Bogdan, kut. 24, bijela košuljica 245.

36 „Vaša je stvar za nas važna: 1) što je tamo razjašnjeno i naše pitanje i, 2) što i mi moramo konačno imati hrvatskog marksistu koji u svijetu mora steći reputaciju, kakvu su stekli u prvom redu Djilas i Mihajlov - naime važno je da se s marksističkih pozicija iznese i hrvatski problem, i vi ste za to nesumnjivo najpozvaniji. Kao što znate, iznositi naš problem sa predratnih i ratnih nacionalističkih pozicija nema nikakve vrijednosti. Naprotiv, to nam samo škodi.” Pismo Bogdana Radice iz New Yorka za Franju Tuđmana od 7. travnja 1978. HR-HDA-1769-Radica Bogdan, kut. 24, bijela košuljica 245 .

37 „Vaše prijeratno razmatranje u švicarskom tisku o balkanizaciji i skandinavizaciji, razumije se nije mi bilo poznato, ali nije nikakvo čudo što smo iz analize sličnih prilika došli do analognih misli i zaključaka..." Pismo Franje Tuđmana od 2. svibnja 1978. za Bogdana Radicu. HR-HDA-1769-Radica Bogdan, kut. 24, bijela košuljica 245.
} 
progon i suđenje. Radica drži da je mnogo važnije da osoba Tuđmanova profila ostane kod kuće, osim ako nije pod prijetnjom onoga najgoreg. Ako pak misli da mora otići van, Radica drži da bi dolazak u Ameriku svakako bio najbolji. Argumentira to činjenicom da je Tuđman najkorisnije što je izašlo iz „hrvatskoga proljeća”, a oni koji su došli u novom emigrantskom valu nisu od neke političke i intelektualne koristi, pa bi jedan autoritet poput Tuđmanova bio veoma dragocjen. Zato Radica apelira da bi bilo od vitalne važnosti da se ponovno sretnu na istome mjestu gdje su se upoznali, misleći na vilu kraj Firence, da bi mogli razmijeniti i uskladiti stavove te se osvrnuti na Tuđmanov nastup na švedskoj televiziji i njegove prijedloge o konfederaciji i skandinavizaciji kao modelima $\mathrm{u}$ rješavanju jugoslavenske krize, o čemu je Radica pisao još prije rata. ${ }^{38}$ Radica posebno naglašava da će od lipnja do listopada biti u Italiji, ostavljajući Tuđmanu svoj broj telefona iz Firence, aludirajući na možebitni susret.

\section{Početak misije}

Sama „operacija” prenošenja rukopisa knjige preko državne granice obavljena je u ljeto 1978., kada je obitelj Tuđman bila na godišnjem odmoru u Umagu, gdje su tada ljetovali i supružnici Višnja i Fredi Kramer. Ankica je zamolila prijateljicu Višnju da 3. srpnja skupa otputuju na jedan dan preko granice u Trst da obave kupnju, ne spominjući joj da u torbi nosi „atomsku bombu” u obliku spisa Tuđmanove buduće knjige. S obzirom na tadašnje okolnosti vezane za Tuđmana, u svjetlu njegove osude, zatvora i zabrane svakoga javnog djelovanja, to uopće nije bila bezazlena akcija i eventualnim otkrivanjem mogla je dodatno otežati situaciju obitelji Tuđman, a Kramerove dovesti u jako neugodan položaj. Primjerice, Miroslav Vaupotić osuđen je na četiri godine zatvora samo zbog onoga što je pribilježio u osobnom dnevniku koji su mu našli prilikom pretresa stana, ${ }^{39}$ a postoji bezbroj primjera iz tadašnje sudske prakse kad su pojedinci dobivali višegodišnje zatvorske kazne zbog pisanja letaka neprijateljskoga sadržaja ili neprikladnih pisama predsjedniku Titu. Razumljivi su stoga strah i nervoza Ankice Tuđman koje je izazvala neuobičajena gužva i detaljni pretresi na granici prema Italiji, i bezbrižna drskost koju je pokazala Višnja u razgovoru s carinicima, te se pokazalo mudrim što Ankica nije prijateljici otkrila narav puta u Italiju. Došavši u Trst, Ankica je morala prenoćiti jer je prvi vlak za Firencu vozio tek ujutro. Idućega je dana napokon

\footnotetext{
38 „Tek sad je bitno jedno da se riješi Vaš slučaj u jednom ili u drugom pravcu kao i Vaš rukopis. Ne obraćajte se više na nikog jer onako sve to jedini sam u stanju izvršit. Prije svega i nad svime, čuvajte se, jer ste Vi jedini koji je našem nesretnom narodu od najveće potrebe." Pismo Bogdana Radice iz New Yorka za Franju Tuđmana od 7. travnja 1978. HR-HDA-1769-Radica Bogdan, kut. 24, bijela košuljica 245 .

39 F. TUĐMAN, Osobni dnevnik, knj. I (1973. - 1978.), 243.
} 
došla do Firence u vilu obitelji Radica i ondje provela tri dana. Radica je još iste noći pročitao donesene materijale te s ushićenjem govorio Ankici da se radi o izvrsnom štivu koje će on odnijeti u SAD i dati tiskati na engleskom jeziku kod poznatoga nakladnika i njegova poznanika Vlade Jovanovicha u New Yorku, u tadašnjoj američkoj javnosti poznatijega kao William Jovanovich. Ta je knjiga doista i tiskana, ali tek nakon nekoliko godina i stanovitih poteškoća, 1981. u izdanju Columbia University Pressa. ${ }^{40}$

Zanimljivo je da je ugovor o objavi knjige potpisao sin poznatoga kipara Ivana Meštrovića Mate Meštrović, koji je živio u Americi i bio u kontaktu s Tuđmanom, iako nije imao autorovo odobrenje za to, a bio je i pod obradom SDS-a, što je dodatno kompromitiralo optuženoga Tuđmana, ne ulazeći u možebitnu materijalnu korist koju je Meštrović imao od prodaje knjige. ${ }^{41}$ To je bilo osobito delikatno za samoga Tuđmana jer je upravo u to vrijeme bio u tijeku novi proces protiv njega i prvo veliko suđenje nakon Titove smrti. I hrvatski politički emigrant Vinko Nikolić tiskao je u Hrvatskoj reviji bez Tuđmanova znanja istu knjigu, ali na hrvatskom jeziku, uz korektno objašnjenje da je to piratsko izdanje. Kako je prvo izdanje ubrzo rasprodano, Nikolić je odmah tiskao i drugo izdanje. ${ }^{42}$

Istoga dana kad je Ankica krenula za Italiju datirano je i Tuđmanovo pismo (pretpostavljamo da ga je ponijela) za Radicu u kojem ga obavještava da mu šalje rukopis knjige. Tuđman u pismu ističe da ni sâm nije baš najzadovoljniji tekstom, međutim u trenutačnim uvjetima, u kojima nije mogao doći do inozemne literature, a izostala je i temeljna redaktura zbog žurbe vezane za situaciju u Jugoslaviji, ipak se odlučuje poslati rukopis dok za tu temu još vlada širi međunarodni interes i „dok mi je to moguće”. ${ }^{33}$ Tuđman u pismu postavlja retoričko pitanje glede izbora izdavača koji bi mogao tiskati knjigu na više jezika s obzirom na aktualnost i sadržaj njegove buduće knjige Nacionalno pitanje u suvremenoj Europi. Naime, iz same knjige iščitavamo povjesnika Tuđmana koji obrađuje zabranjenu temu u jugoslavenskom znanstvenom miljeu, koji se godinama bavio pitanjima i društvenim silnicama vezanim za (hrvatsko) nacionalno pitanje, ne samo u

\footnotetext{
40 A. TUĐMAN, Moj život s Francekom, 219.

${ }^{41} \mathrm{U}$ informativnom razgovoru koji je na zahtjev SDS-a obavljen s Tuđmanom on se osvrće na ovaj slučaj u smislu da je Meštroviću predbacio što je 1981., kad je Tuđman bio pred suđenjem, kopirao njegov rukopis Nacionalno pitanje u suvremenoj Europi i objavio ga u knjižnici emigrantskoga časopisa Hrvatska revija, koji je u Jugoslaviji slovio kao glasilo fašističke emigracije. Na Tuđmanovu opasku da mu je to na suđenju bila otežavajuća okolnost, Meštrović mu je odgovorio „da bi Tuđman svakako bio osuđen sa ili bez objavljenog teksta”. MALETIĆ, Dr. Franjo Tuđman. Dosje br. 229562, 946. Radi se o dokumentu RSUP SDS, Centar Zagreb, od 3. studenog 1988. Informacija broj 1457.

42 A. TUĐMAN, Moj život s Francekom, 220.

43 Pismo Franje Tuđmana od 3. srpnja 1978. za Bogdana Radicu. HR-HDA-1769-Radica Bogdan, kut. 24, bijela košuljica 245.
} 
tadašnjoj Jugoslaviji, nego u cijeloj Europi i svijetu. Točno predviđajući ubrzane trendove globalizacije i integriteta, on pokazuje da je nužan proces samoodređenja naroda, a pravo na vlastitu državu drži temeljnim pravom, poglavito malih naroda. Bez toga će neprestano tinjati nezadovoljstva, antagonizmi i nemiri, a to usporava i ekonomiju, vladavinu prava, pa i samu integraciju svijeta. Zato pravo na samoodređenje, tj. vlastitu državu svakoga naroda ,jedno je od osnovnih i najbitnijih pitanja mira u svijetu i stabilnosti svakoga međunarodnog poretka”, ${ }^{44}$ jer su integracijski procesi kojima je cilj ujedinjenje Europe u trajnoj opasnosti i osuđeni na neuspjeh ako se to zanemari. Kao potvrdu svojih teza glede nužnosti takvih procesa on iznosi činjenice „o stalno rastućem broju država u Europi i svijetu kad je OUN, nakon Drugog svjetskog rata, u ljeto 1945. započinjala sa svojim radom, imala je svega 51 članicu, godine 1960. već su 82 države bile članice te svjetske organizacije, a do godine 1978. broj nezavisnih država-članica OUN popeo se na 138, a predviđanja predskazuju, da će ih potkraj ovog stoljeća biti više od 200" ${ }^{45}$ I zbilja, te njegove proročke riječi aktualne su i suvremene i danas, četrdeset godina od njihova objavljivanja, a tvrdnja da je „zadovoljenje nacionalnih težnji svih europskih naroda bitna pretpostavka za stabilnost novoga međunarodnog poretka u ujedinjenoj Europi”, poglavito ona „o nužnosti priznanja i nacionalne suverenosti svim nesamostalnim i stoga nezadovoljnim narodima”, ${ }^{46}$ bila je u ono vrijeme partijske represije sigurna osuda za autora tih tekstova $\mathrm{u}$ nedemokratskoj jugoslavenskoj zajednici opterećenoj neriješenim nacionalnim pitanjima i krizama koje su na kraju dovele do njezina tragična kraja.

Tuđman ne dvoji o važnosti sadržaja knjige te u pismu Radici izražava uvjerenje da će izazvati širi interes u svjetskoj javnosti s obzirom na to da je gotovo sva dotadašnja literatura glede hrvatskoga pitanja nedovoljna i jednostrana, pa bi se i zbog toga trebalo potruditi da se rukopis prevede na što je više moguće svjetskih jezika. ${ }^{47}$ Tuđman traži Radičino mišljenje u svezi s pismenom ponudom za neki njegov rukopis koji bi mu tiskali na engleskom koju je još prije dvije godine dobio od američkoga izdavača Vlade Jovanovicha iz nakladničke kuće Harcourt Brace Jovanovich. Pismo završava važnim upozorenjem s obzirom na tadašnji Tuđmanov „prekaran položaj” i možebitne posljedice koje će izazvati tiskanje knjige, a kojih je on itekako svjestan. Tuđman poziva Radicu da do izlaska knjige nikomu ne govori o njoj, da se tiskanje uredi ugovorom između njega i nakladnika da bi se izbjegle sve negativne konotacije i zaštitila njegova autorska prava, te da se ne dopusti tiskanje

\footnotetext{
$44 \quad$ F. TUĐMAN, Nacionalno pitanje u suvremenoj Europi, 222.

45 Isto, 217.

$46 \quad$ Isto, 228.

47 Pismo Franje Tuđmana od 3. srpnja 1978. za Bogdana Radicu. HR-HDA-1769-Radica Bogdan, kut. 24, bijela košuljica 245.
} 
izvadaka iz knjige u emigrantskom tisku sve dok knjiga ne bude objavljena. ${ }^{48}$ Na kraju toga pisma, kao i u nekoliko drugih, stoji zloguki navještaj onoga što ga u budućnosti čeka ili će ga čekati, odajući time rezolutnost čovjeka koji je odlučio - usprkos činjenicama i signalima iz partijskoga vrha koji su Tuđmanu tijekom prvoga uhićenja i utamničenja 1972. pokazali svu beskrupuloznost aktualnoga totalitarnog režima - i koji je spreman žrtvovati ugled, komfor generalske mirovine, svoj život, pa i vlastitu obitelj, zbog promicanja istine i svojih moralnih i znanstvenih stavova. ${ }^{49}$ Takav završetak pisma treba uzeti krajnje ozbiljno i bez zadrške. Iz njega jasno proizlazi da Tuđman, iako neosporno emotivan i tankoćutan čovjek, nikako nije kukavica i šarlatan. Pogotovo kad se radi o ovako ozbiljnim stvarima koje su vezane za njegovu sudbinu. To baca sasvim novo svjetlo na njegov boravak u pritvoru tijekom istražnoga postupka u Petrinjskoj 18 i kratke boravke u zatvorskoj bolnici. ${ }^{50} \mathrm{Na}$ više mjesta u svojem zatvorskom dnevniku Tuđman opisuje rapidno pogoršanje zdravlja nakon uhićenja 11. siječnja 1972. godine. Sada u drugom svjetlu možemo gledati i njegovo odbijanje konzumiranja zatvorske hrane. Naime, malo je poznato da je tijekom boravka u pritvoru u Petrinjskoj 18 cijelo vrijeme jeo isključivo hranu koju mu je spremala supruga Ankica. Nije nebitna činjenica da je bio odlučan inzistirati na tome da mu se dopusti primati hranu izvana pod prijetnjom štrajkom glađu, a kad su počele nesvjestice, neurološki i srčani ispadi, odrekao se i lijekova. Bitno je istaknuti da je Tuđman od samoga početka zatvaranja zauzeo takav stav time što je odbijao trošiti lijekove koji nisu tvornički zapakirani. ${ }^{51}$ Jamačno nije slučajno što je cijelo jedno poglavlje svoje knjige o suđenju Tuđmanu odvjetnik Milan Vuković naslovio „Strah od trovanja u zatvoru". ${ }^{52}$ Očita je njegova svjesnost situacije te žurnost da se knjiga objavi, kako on kaže u pismima, „dok još ima mogućnosti za to”, svjestan da ga čega nastavak obračuna koji je započet s njim sedamdesetih godina XX. stoljeća, a koji će se nastaviti, kao što znamo, nakon smrti Tita i književnika Miroslava Krleže u prvom velikom političkom procesu nakon Titove smrti 1980. godine. Cjelokupnu operaciju praćenja, marginaliziranja, uhićenja, suđenja, pritvaranja, pa ponovnoga suđenja koju je SDS proveo protiv Tuđmana najbolje bismo

\footnotetext{
48 Isto.

49 Pismo završava ovako: „PS: Ako bi se meni što dogodilo, molim da se sva pitanja urede u dogovoru s mojom suprugom.” Isto.

50 „Od neurodermatitisa koža mi gori kao da sam stalno išiban koprivama ili opečen od sunca, kao da imam sunčanicu. Glavobolje nikad nisam imao, a sad [...] da me ponekad hvata nesvjestica, da gubim osjećaj: ispada mi boca, čaša, tanjur, ruka i noga su mi crne od udaranja u stol... O moj živote, dokle stigoh.” F. TUĐMAN, Petrinjska 18, 615-616.

${ }_{51}$ „Lijekove raznosi, po jednu tabletu, tri puta dnevno, neka osoba u bijelom radnom kaputu; nije mi htio odgovoriti je li bolničar ili službenik. Uzimam tablete (tvornički omotane), C vitamina i galypirina, a odbijam oblivion (?) koji mi nosi rastopljen u bočici.” Isto, 39.

52 VUKOVIĆ, Dr. Franjo Tudman u sudskim dosjeima, 17.
} 
mogli sažeti u riječi kojima je Tuđmana upozorio brat njegove supruge Franjo Žumbar, rezervni kapetan Jugoslavenske narodne armije, u to vrijeme na radu u Nuklearnoj elektrani Krško, koji je godinama izbjegavao Tuđmana - što dovoljno govori kakva je psihoza vladala tih godina, ali ga je ipak upozorio na slučajnom susretu kod Tuđmanova sina Miroslava 1981. godine. Kako je svaki pisani materijal u tadašnjem jugoslavenskom pravosuđu mogao postati krunskim dokazom za optužnicu, Tuđman je svoje zapise uglavnom pisao ezopovski: „Neki dan kod Mireka” (Miroslav Tuđman, op. a.) „- Ujčinovski” (Franjo Žumbar, op. a.) „poslije nekoliko godina odsutnosti, najmanje četiri. Neka shvatimo da je on u takvom poslu da mora svakodnevno surađivati; da se svaki dolazak kod nas snima; da se čuvam jer da mu je čovjek službe rekao da se bave mišlju kako da me 'fizički srede', možda ne posve, ali - onesposobe; da ne bi smio ni koraka sam..." ${ }^{53}$ I doista, to kao da su bile proročke riječi koje su se ispunile na Tuđmanu, koji je bio zahvaćen torturom koju je SDS razvio do perfekcije da bi raznim tehnikama i pritiscima izazvao strah i paranoju kod stigmatiziranih osoba dovevši ih u stanje dezorijentacije i šoka, da bi se i na taj način neutralizirale, prisilile na suradnju ili pasivizaciju. To je kao iskusni novinar zapazio i Radica prilikom svojega kratkotrajnog angažmana i rada za silom uspostavljeni komunistički režim 1945., uvjerivši se iz prve ruke da su teror i zastrašivanje najvažniji elementi na kojima počiva i počivat će partijska diktatura s jasnom intencijom „da vas obeshrabri, zamori ili baci u jedno letargijsko stanje, kad vam sve postaje indiferentno i monotono, i kad bi samo htjeli da negdje, u nekom udaljenom i tamnom prostoru usnete i spavate čitave dane i noći”. ${ }^{4}$

\section{Problemi s nakladnikom}

Odmah nakon što je Ankica Tuđman uspješno dostavila rukopis i vratila se u Hrvatsku, Franjo Tuđman 17. srpnja 1978. žurno upućuje novo pismo Radici u L'Ulivello kraj Firence, znajući da je on u Italiji samo preko ljeta. U pismu mu zahvaljuje na gostoprimstvu koje su pružili Ankici, a osobito na brizi za njegove rukopise. Tuđman i u tom pismu ističe da je važno da prije negoli knjiga iziđe kod nekoga stranog nakladnika ne izađe ništa iz emigrantskoga kruga zbog njegove teške situacije kod kuće (izlazak iz zatvora i zabrana javnoga djelovanja), da ne bi preskupo platio tiskanje te knjige. Tuđman piše da i njegovi prijatelji u Švedskoj rade na tome da se knjiga tiska na švedskom i njemačkom te eventualno engleskom jeziku, pa preporučuje da se oni međusobno koordiniraju kako ne bi uspjeli oni koji ne žele dopustiti njezino tiskanje. Za

$53 \quad$ F. TUĐMAN, Osobni dnevnik, knj. II (1979. - 1983.), 129.

54 RADICA, Hrvatska 1945., 79. 
preostala dva primjerka rukopisa koja su kod Radice Tuđman sugerira neka ih pošalje „,gosp. S” (Branku Salaju, op. a.) ,ili gosp. R” (Vladimiru Rozijanu, op. a. ${ }^{55}$, „već prema tome koji vam se javi”. Na kraju moli Radicu da mu odmah po eventualnom odgovoru američkoga izdavača Jovanovicha preko sigurne veze iz Beča dostavi njegove uvjete. ${ }^{56}$

Uzevši u obzir Tuđmanove sugestije o potrebi zajedničkoga i usklađenoga djelovanja u naporima za objavu njegove knjige, Radica piše pismo poznaniku s jednoga od sajmova knjiga u Frankfurtu, Vladimiru Rozijanu u Lund, kome je preporučenom poštom poslao Tuđmanov rukopis u skladu s telefonskim razgovorom koji se vodio između Radice, Ankice Tuđman i Rozijana. Radicu je posebno zanimalo imaju li oni u Švedskoj prevoditelja za engleski jezik da ga on ne bi morao tražiti u Londonu ili New Yorku. Ako imaju, Radica je posebno sugerirao da to mora biti stranac, a nikako Hrvat, iz dobro znanih razloga. U nastavku pisma Radica je iznio mogućnost da njihov „zajednički prijatelj” dođe do njega (misleći na Tuđmanov dolazak u Toskanu), ali o tome bi on svakako obavijestio telefonski i Rozijana i Branka Salaja. Međutim, postojao je problem koji Radica nije mogao sam riješiti. Naime, Tuđman je, prema navodima iz pisma, trebao doći u Kopar, a ondje ga je netko onda trebao uzeti u auto i prebaciti u L'Ulivello kraj Firence do Radice. Ali Radica kaže da on u tom trenutku nema nikoga tko bi to učinio jer je njegov prijatelj Amerikanac koji je to bio spreman izvesti morao otputovati. Zato je Radica predložio njima u Švedskoj da osobno dođu to izvesti, ako mogu, jer je svako zadržavanje na liniji Trst - Padova - Venecija opasno, misleći na prijetnje SDS-ovih agenata. ${ }^{57}$

U toj konstelaciji između Tuđmanovih nastojanja da renomirani inozemni nakladnik što prije objavi knjigu i „nedoumica glede prijevoda“, Rozijan je odgovorio na Radičino pismo (nakon što mu je Radica pisao 12. srpnja 1978.) da pokušaju sinkronizirati svoja djelovanja. On kaže da je nakon korespondencije s Tuđmanom stekao dojam da postoji neka vrsta ugovora s nakladnikom Harcourt Brace Jovanovich i da Radica već ima riješeno pitanje prevođenja rukopisa. U svakom slučaju, Rozijan ističe da njihova izdavačka djelatnost ne pokriva englesko govorno područje te oni nemaju rješenje za prijevod. Rozijan je otvorio i temu koja je po njemu bila iznimno važna, a radilo se o informacijama koje je dobio preko kontakata iz Zagreba i Radičinih članaka u kojima je

${ }_{55}$ Branko Salaj i Vladimir Rozijan bili su poznatiji aktivisti u hrvatskoj političkoj emigraciji. Početkom sedamdesetih inicirali su osnivanje Društva prijatelja Matice hrvatske te bili pokretači kulturnih aktivnosti hrvatskih useljenika u Švedskoj. Poglavito su se istaknuli u borbi za priznanje hrvatskoga jezika (u učenju materinskoga jezika u školama u Stockholmu i Lundu), što je prvi takav slučaj u tadašnjoj Europi kad je u pitanju hrvatska emigracija.

56 Pismo Franje Tuđmana za Bogdana Radicu od 17. srpnja 1978. HR-HDA-1769-Radica Bogdan, kut. 24, bijela košuljica 245 .

${ }^{57}$ Pismo Bogdana Radice od 12. srpnja 1978., L’Ulivello, za Vladimira Rozijana. HR-HDA-1769-Radica Bogdan, kut. 24, bijela košuljica 245. 
pisao o tome. Radilo se o uspostavi kontakta između Milovana Đilasa i „naše ekipe" u Zagrebu. On je držao da je ta inicijativa veoma važna jer može pokrenuti neke reakcije vladajućih u Beogradu i Zagrebu, na temelju kojih se onda treba postaviti demokratska oporba u domovini. ${ }^{58}$ Rozijanu je očito poznato da se Đilas u Zagrebu susreo s Markom Veselicom, Hrvojem Šošićem, poslije i Ivanom Zvonimirom Čičkom i Draženom Budišom, a 13. lipnja 1978. posjetio je i Tuđmana u njegovu stanu, gdje se zadržao više sati. ${ }^{59}$

Toga se ljeta u svezi s knjigom očito ništa nije događalo, pa Tuđman 22. rujna 1978. ponovno šalje pismo u kojem izražava žaljenje što se ne mogu osobno susresti te detaljno nabraja stranice rukopisa na kojima treba napraviti ispravke. Uglavnom se radi o malim dopunama i „daktilografskim pogreškama" koje će Radica popraviti prije tiskanja. Tuđman također priopćuje Radici novost vezanu za nakladnika Harcourt Brace Jovanovich, kojima se on još prije pismeno obratio uz prijedlog o mogućoj suradnji u izdavanju njegova rukopisa. Jovanovich ga je nazvao i zatražio da mu se pošalje original rukopisa jer ga je želio usporediti s rukopisom slične tematike koji je pisao publicist i novinar te suradnik The Economista Krsto Cviić, koji je već imao potpisan ugovor s njegovom izdavačkom kućom. ${ }^{60}$ Tuđman također u tom pismu kaže da mu je još prije dvije godine Jovanovich ponudio suradnju u vezi s tematikom hrvatskoga pogleda na stanje u Jugoslaviji, a Tuđman mu je već tada predložio svoj rukopis Nacionalno pitanje u suvremenoj Europi. ${ }^{61}$ Na kraju Tuđman moli Radicu, budući da on ubrzo ide u New York, neka preda Jovanovichu originalni rukopis knjige koji je kod njega s dopunama i ispravcima i na licu mjesta raščisti situaciju s njime da ne bi uludo gubili vrijeme, te mu poimenično preporučuje još neke američke nakladnike, očito sluteći epilog situacije s

\footnotetext{
58 „Promicanje taktičke igre i postavljanje novih uvjeta zavisi kao što to i vi mislite od vodstva u domovini, i zato su naši dodiri s T [misli na Tuđmana, op. a.] od velike važnosti. Ja sam vam se javio telefonom samo zato da vidim da li ste kod kuće, jer je T prilikom prošlog boravka vani izrazio naročitu želju da se s Vama porazgovori. Dakle trenutak za razgovor još nije tu ali ja mislim da bi se sastanak mogao upriličiti za vrijeme sajma knjiga u Frankfurtu. Operativna odgovornost leži, kao i prije, na Branku i meni." Pismo Vladimira Rozijana za Bogdana Radicu od 29. srpnja 1978. HR-HDA-1769-Radica Bogdan, kut. 24, bijela košuljica 245. Tu izjavu o Tuđmanovu „prošlom boravku vani” Rozijan je potvrdio sudjelujući u reportaži HRT-ova novinara Dragana Nikolića iz Švedske 11. travnja 2017., u kojoj svjedoči da je u Lundu ugostio i Franju Tuđmana na njegovu prvom inozemnom putovanju s lažnom putovnicom. NIKOLIĆ, „Hrvati žive svoj švedski san”. U Tuđmanovu dosjeu imamo popise ljudi koji su mu čestitali Novu godinu ili ga pozvali na kavu, međutim o tom putovanju „van” nema ništa!?

$59 \quad$ F. TUĐMAN, Osobni dnevnik, knj. I (1973. - 1978.), 401.

60 Pismo Franje Tuđmana za Bogdana Radicu od 22. rujna 1978. HR-HDA-1769-Radica Bogdan, kut. 24, bijela košuljica 245.

${ }_{61}$ „Pri tom sam mu naveo da medju ostalim imam u planu pripremu rukopisa 'Tito između Churchilla i Staljina’ (radni naslov) na temelju izvornih dokumenta i pismene ostavštine dra Ivana Šubašića, pred. Kr. Jug. vlade i ministra vanjskih poslova u Titovoj vladi i dra Jurja Šuteja, ministra u obje vlade, koja je ostavština meni oporučno ostavljena." Isto.
} 
Jovanovichem. Predložio je Radici i da pronađe put do američkoga političara Laurencea Hirscha Silbermana, bivšega američkog veleposlanika u Jugoslaviji (1975. - 1976.), koji je bio opozvan nakon nepune dvije godine službe jer je bio u permanentnom sukobu s jugoslavenskim vlastima. O tome najbolje govori članak objavljen na naslovnici New York Timesa „Tito Attacks U.S. Envoy For 'Pressure Campaign'". Članak citira Titov napad na veleposlanika Silbermana $i$ ističe da je to prvi put da je otvoreno prozvan jedan strani diplomat. ${ }^{62}$ Napetost između veleposlanika Silbermana i njegova osoblja s jedne strane i jugoslavenske vlade s druge strane izazivale su njegove kritike poradi kršenja ljudskih prava, a dijelom i zbog zatočeništva u Jugoslaviji Laszla Totha, američkoga državljanina. ${ }^{63}$ Tuđman je Radici preporučio za kontakt i Daniela Patricka Moynihana,${ }^{64}$ uglednoga američkog političara, sociologa i diplomata, kojemu bi Radica trebao objasniti smisao i značenje Tuđmanovih rukopisa jer on može dati najbolji savjet za odabir i preporuku američkim nakladnicima za tiskanje knjige. Na te Tuđmanove savjete i sugestije, kojima na neki način potiče Radicu na žurbu i akciju - očito sluteći svoje uhićenje, Radica 4. listopada 1978. odgovara dužim pismom u kojom opisuje korake koje je poduzeo, izražavajući i duboku brigu glede situacije s rukopisom. Prije svega Radica kaže da mu Salaj i Rozijan ne odgovaraju na brojna pisma koja je poslao u Stockholm, a vezano za Tuđmanov prijedlog iz posljednjega pisma od 22. rujna, u kojemu mu predlaže da po povratku u SAD preda rukopis Jovanovichu, Radica piše da je prije negoli je krenuo za Italiju napravio presliku rukopisa i ostavio ga kod svoje kćeri Bosiljke. Odmah nakon što je primio Tuđmanovo pismo nazvao ju je i objasnio joj sve o rukopisu i kako da ga preda Jovanovichu na čitanje. Radica napominje i da će izmjene u tekstu koje mu je Tuđman poslao on sam unijeti tijekom prijevoda prevoditelja kod Jovanovicha - ako oni budu

\footnotetext{
62 „President Tito has harshly enounced the United States Ambassador to Yugoslavia as having initiated a 'campaign' against Yugoslavia, according to remarks made public today. Marshal Tito's direct verbal attack on Ambassador Laurence H. Silberman was the first time in memory that the Yugoslav head of state had singled out any foreign diplomat by name for such criticism." Malcolm W. BROWNE, „Tito Attacks U.S. Envoy For 'Pressure Campaign”', New York Times (New York), 1. 8. 1976., 1 [„Predsjednik Tito oštro je prozvao veleposlanika Sjedinjenih Država u Jugoslaviji da je započeo 'kampanju' protiv Jugoslavije, sudeći prema danas objavljenim primjedbama. Koliko znamo, izravni verbalni napad maršala Tita na veleposlanika Laurencea H. Silbermana prvi je slučaj da je jugoslavenski šef države poimence prozvao nekoga stranog diplomata zbog takvih kritika.” Malcolm W. BROWNE, „Tito napada američkoga izaslanika zbog 'kampanje pritiska”'].

63 Toth je bio uhićen 1975. zbog navodnoga fotografiranja jugoslavenske rafinerije šećera u kojoj je radio prije nego što je emigrirao u Ameriku. Optužen je za špijuniranje i osuđen na tajnom suđenju na sedam godina zatvora.

64 Kad citira Radičin članak „Uslijed čega šute”, Tuđman u svojem dnevniku spominje Moynihana, koji je postao jedan od najpopularnijih američkih diplomata zbog svojega stava prema komunističkoj propagandi, uz napomenu da su tekst Brune Bušića o zatvaranju Hrvata poslali jugoslavenskom veleposlaniku, senatorima, kongresnicima, a i sam Henry Kissinger upoznat je s njim. F. TUĐMAN, Osobni dnevnik, knj. I (1973. - 1978.), 255.
} 
pristali na tiskanje - jer su se s njim konzultirali i za prijevode Đilasovih knjiga Nova klasa i Besudna zemlja, čiji su rukopisi došli u Radičine ruke i prije nego što je Jovanovich znao za njih. ${ }^{65} \mathrm{U}$ nastavku pisma Radica je iznio svoje iznenađenje u vezi sa senzacionalnim novim naslovima koje Tuđman planira napisati te ih spominje u posljednjem pismu, čudeći se da je Ivan Šubašić bio toliko pametan i ostavio Tuđmanu svoju arhivu jer za takvo što nije mogao naći boljega čovjeka. Radica predmnijeva da ga je u toj stvari jamačno savjetovao Juraj Šutej - jedan od najrealnijih hrvatskih političara uz Mačeka („zašto ne i Tita!” napominje Radica). Komentirajući Tuđmanovu sugestiju o preporuci za rukopis Silbermana ${ }^{66}$ i Moynihana, Radica drži da bi od Silbermana, s kojim je imao osobni kontakt, mogao ishoditi javnu preporuku za knjigu kad iziđe, što bi imalo veliko značenje za širu javnost, a misli da od Moynihana trenutačno nema koristi jer je kao senator prezauzet drugim stvarima. U drugom dijelu pisma Radica se osvrće na aktualnu situaciju u Jugoslaviji, žaleći što se toga puta nisu mogli susresti da valoriziraju određene teme, a ponajprije percepciju zapadnih centara o mogućnosti upada Sovjeta u Jugoslaviju zbog srpsko-hrvatskih antagonizama, o čemu se sve više piše u zapadnom tisku. Radica u pismu promišlja da u određenim srpsko-crnogorskim krugovima postoji stanoviti broj prosovjetskih elemenata, ali uslijed neodgovornih napisa Brune Bušića i Zlatka Markusa u emigrantskom tisku, koji promišljaju o hrvatskoj potpori sovjetskoj intervenciji u Jugoslaviji ako bi oni Hrvatima ponudili državu, pa se onda takav pogrešan dojam odašilje u inozemnu javnost. Tu bi, po Radičinu mišljenju, sam Tuđman mogao odigrati izvjesnu ulogu u smislu da upozori te ljude neka odustanu od neozbiljnih i neodgovornih stavova. Kroz prizmu Tuđmanovih još neobjavljenih rukopisa Radica je promišljao o tadašnjoj kratkovidnosti jugoslavenskih političara, koji su u Karađorđevu maknuli hrvatsko političko rukovodstvo, koje je na neki način moglo „ne samo ispraviti situaciju nego i spasiti stvar, da i opet ne dodje do srpsko-hrvatskog krvavog obračuna. Trebalo bi imati malo više uvidjavnosti i fleksibilnosti dok ima vremena!". ${ }^{67}$ Radica navodi naučenu povijesnu lekciju kad je predratni Beograd pod namjesnikom Pavlom Karađorđevićem zaključio da treba kori-

65 „Iz pisma Jovanoviću osjetit ćete da sam mu na jednom mjestu polaskao ne toliko iz uvjerenja koliko da ga zagrijem da izda vašu knjigu, jer je to ipak jako poduzeće”, a svi drugi nakladnici koje Tuđman spominje u pismu nisu toliko poznati niti imaju toliko kvalitetne prevoditelje kao Jovanovich, drži Radica. Osim toga s drugim nakladnicima tek bi počeli s pregovorima, a to bi trajalo. Pismo Bogdana Radice od 4. listopada 1978., L'Ulivello, za Franju Tuđmana. HR-HDA-1769-Radica Bogdan, kut. 24, bijela košuljica 245.

66 U dnevniku Tuđman na više mjesta spominje Silbermana, čiji je rad očito pratio: „L.H. Silberman objavljuje u 'Foreign Policy' da se u Jugoslaviji krše ljudska prava kao i u drugim istočnim zemljama; kaže da je u Beograd došao kao prijatelj Titove Jugoslavije ali je svoje poglede morao 'premisliti u negativnom smislu'." F. TUĐMAN, Osobni dnevnik, knj. I (1973. - 1978.), 320.

67 Pismo Bogdana Radice od 4. listopada 1978., L'Ulivello, za Franju Tuđmana. HR-HDA-1769-Radica Bogdan, kut. 24, bijela košuljica 245. 
girati i uvažiti te stvari glede hrvatskoga pitanja kad je već bilo kasno, izražavajući bojazan da će i „ovi današnji” kasno shvatiti nužnost promjena (o čemu govore i Tuđmanovi rukopisi). Radica je smatrao da se ulazi u već viđenu shemu: rušenje prve Jugoslavije, za koje su izravno odgovorni Srbi, a optuženi su Hrvati, kao što su optuženi i za dovođenje Adolfa Hitlera na Balkan, a tako će biti optuženi za dovođenje Rusa na Jadran kao izravne posljedice neriješenoga nacionalnog pitanja u Jugoslaviji. Zbog svega toga Radica poentira mišlju da je baš zato važna ta Tuđmanova knjiga, koja će po njegovu mišljenju, usprkos svim poteškoćama, sigurno biti tiskana. A poteškoća je bilo. Iako je Tuđman pokušao osigurati tiskanje preko Londona, Stockholma i New Yorka, uključivši u to Brunu Bušića, Branka Salaja i Bogdana Radicu, dobro procijenivši da je rizično igrati samo na jednu kartu, stvari su krenule nepovoljno i u svezi s njegovom situacijom kod kuće i u svezi s knjigom. U pokušaju da na neki način koordinira traženje izdavača i prevoditelja knjige, Tuđman 2. prosinca 1978. ponovno piše Radici, sada u SAD, obavještavajući ga da mu u prilogu dostavlja pismo koje je poslao Velimiru Suliću jer je tek saznao da je Bruno Bušić (inače, u pismima Tuđman često koristi inicijale i pseudonime zbog sumnje da ga prati SDS, pa tako nigdje ne piše Bušićevo ime, nego koristi pseudonim „Brub”) upravo Suliću poslao rukopise koje mu je Tuđman predao, vjerojatno tijekom ilegalnoga boravka ${ }^{68}$ u Švedskoj i Njemačkoj, koje je ovaj potom odnio u London. Tuđman je držao da će pregovori s Jovanovichem ili eventualno novim nakladnikom potrajati, a Bušić je inzistirao jer je imao, prema njegovim riječima, povoljne uvjete za prijevod, pa mu ih je zato povjerio. Pošto je Bušić likvidiran 16. listopada 1978., dakle dva mjeseca prije nego što je pisano to pismo, Tuđman pokušava pohvatati konce u svezi s tiskanjem knjige iako je, kako je više puta ponavljao u pismima, već bio izgubio previše vremena. Zato moli Radicu da stupi u kontakt sa Sulićem i neka se dogovore o sljedećim koracima i radnjama koje bi trebali uskladiti. Tuđman ističe da glede pronalaženja nakladnika i promidžbe knjige u svjetskoj javnosti najviše povjerenja ima u Radicu, ali mu opet sugerira da ne čeka predugo Jovanovichev odgovor. Na kraju Tuđman napominje da koliko god je važno doći do renomiranoga nakladnika, neizmjerno je važnije da sve to završi u što je moguće kraćem roku. Zbilja djeluje fatalistički koliko puta Tuđman u pismima ističe važnost diskrecije i brzoga završetka tiskanja knjige, kao da je slutio i znao da ga za nešto više od godinu dana čeka ponovno uhićenje i suđenje, ,jer ne znamo što donosi dan a što noć" ${ }^{69}$

\footnotetext{
68 Ankica Tuđman fragmentirano opisuje to putovanje od 20. listopada 1977., govoreći da joj Franjo nije mnogo pričao o tome osim da se susreo s Bušićem, Salajem i Nikolićem. A. TUĐMAN, Moj život s Francekom, 199.

69 Pismo Franje Tuđmana za Bogdana Radicu od 2. prosinca 1978. HR-HDA-1769-Radica Bogdan, kut. 24, bijela košuljica 245.
} 
Nakon dva tjedna Radica je poslao Tuđmanu prilično opširno i u pojedinim dijelovima čak dramatično pismo u kojem je pokušao sumirati dotadašnje aktivnosti i činjenice vezane za tiskanje knjige. Prije svega Radica kaže da je još uvijek u iščekivanju odgovora aktualnoga nakladnika Harcourt Brace Jovanovich jer mu je nakladnikova tajnica telefonski priopćila da je Jovanovich dobio rukopis knjige, koji sad proučava. Bitno je, kako je ona istaknula, da Jovanovich drži da Tuđmanova knjiga nije u koliziji s knjigom koju im je ponudio tadašnji suradnik londonskoga The Economista Krsto Cviić, a Jovanovich će javiti konačnu odluku nakon desetodnevne odsutnosti zbog službenoga puta. No situacija se usložnjava jer Bušićev prijatelj Velimir Sulić sada sâm želi tiskati knjigu i ne želi čekati odugovlačenje Jovanovicha i njegove nakladničke kuće, te je ultimativno dao Radici rok od tjedna dana da se oni očituju. Radica izražava bojazan da će ti mladi prijatelji i suradnici pokojnoga Bušića svojim agresivnim i nerazboritim postupcima upropastiti tu vrijednu inicijativu (kao što su i njega na neki način upropastili) i srozati taj znanstveni rad na običnu emigrantsku rabotu koja neće imati planirani međunarodni učinak. Radica drži da je najopasnije u svemu što ti mladi ljudi ne mogu realno sagledati cijelu situaciju i misle da sve mogu sami, bez ičije pomoći i ozbiljnih poznanstava. Na kraju Radica kaže da će mu biti žao ako ih Jovanovich odbije jer su oni među deset vodećih američkih i svjetskih izdavačkih kuća, s izvrsnim prevoditeljima i neograničenim mogućnostima reklamiranja i distribucije. Kaže da je razgovarao i s Columbia University Pressom i još nekima, primjerice Praegerom, koji su također dobri, ali za njih treba imati gotov prijevod. Pismo završava s više strateških koraka koje je neophodno učiniti s obzirom na trenutačne okolnosti. ${ }^{70}$

U pismu napisanom krajem 1978., nakon što je od Radice saznao da je Bruno Bušić presliku rukopisa knjige Nacionalno pitanje u suvremenoj Europi uputio i profesoru Suliću u San Joseu (Kalifornija), Tuđman ga moli, budući da je iz poznatih razloga ograničen u komunikaciji, da u dogovoru s Radicom i Brankom Salajem te jednim njegovim prijateljem u Švedskoj (misli na Vladimira Rozijana), koji također imaju rukopis, usklade svoje napore da knjiga što prije ugleda svjetlo dana. Tuđman je držao da je krajnje vrijeme da međunarodna javnost i preko njegova rukopisa sagleda hrvatsko nacionalno pitanje iz drugoga kuta. Kako je on uložio veliki napor da napiše takvu znanstvenu

\footnotetext{
70 Radica piše da je Tuđman pogriješio što je rukopis poslao na više strana i sad se to više ne može kontrolirati, a on se ne namjerava svađati s tim mladima. Zato preporučuje Tuđmanu neka tim mladima (mladi oko Velimira Sulića) da na znanje da je Tuđmanov prijedlog bio pokušati kod Jovanovicha, a ako on odbije tiskanje, odmah treba osigurati prevođenje u Londonu. Također u tom slučaju treba pristupiti potrazi za novim američkim nakladnikom, ali u suradnji s Radicom, a osobito im naglasiti da nijedan dio knjige ne smiju nigdje objaviti prije engleskoga izdanja jer bi time kompromitirali cjelokupnu stvar. Pismo Bogdana Radice od 14. prosinca 1978., New York, za Franju Tuđmana. HR-HDA-1769-Radica Bogdan, kut. 24, bijela košuljica 245.
} 
studiju, izlažući i sebe nemalom riziku, moli Sulića za diskreciju i ozbiljnost. Prije svega tražio je da se o rukopisu ne govori i ne piše dok ne izađe engleski prijevod, a tek tada treba pokušati naći zgodno rješenje za hrvatski prijevod da se ne bi pogoršao „moj ionako prekaran položaj”. ${ }^{71}$ Nakon što je napisao to pismo za Sulića Tuđman 4. siječnja 1979. odgovara na Radičine opservacije i prijedloge iz njegova pisma od 14. prosinca 1978., iznoseći mu svoje sumnje u namjere Vlade Jovanovicha, kod koga su njegovi rukopisi već pola godine, ali bez jasnih signala zašto se odugovlači s konačnim odgovorom. Tuđman je molio Radicu za razumijevanje zbog njegove nestrpljivosti i nelagode koju osjeća zbog neizvjesnosti u kojoj ga drži američki nakladnik. Zbog svega toga Tuđman je predložio Radici da mu dade rok do kraja mjeseca (siječnja 1979.) da se izjasni. Osvrćući se na Radičinu opasku da je „rukopise slao na mnoge strane”, Tuđman konstatira da jedino Branko Salaj ima presliku rukopisa, koji će pokušati tiskati za europsko tržište, a da je Bušiću dao presliku isključivo zbog prijevoda u Londonu jer mu je ovaj u više navrata spominjao prevoditelja koji je prevodio i Krležina djela. Tuđman je na kraju i sam izrazio zbunjenost time kako je rukopis dospio u Sulićeve ruke, ali i rekao Radici da je i Suliću poslao pismo nadajući se da će se držati predloženih aktivnosti. ${ }^{72}$

\section{Između knjige i prijetnji}

Prije svih tih nedoumica Radica je na engleskom jeziku ponovno pisao Jovanovichu o Tuđmanovu pismu u kojem mu je on rekao da je razgovarao s Jovanovichem, hvaleći taj njegov čin i susretljivost koju je iskazao Tuđmanu. Jamačno u želji da na neki način zaintrigira nakladnika i ponuka ga na suradnju, Radica iznosi svoju opservaciju da Tuđman s hrvatske i Đilas sa srpske strane, uz snažnu potporu nakladnika u Washingtonu (Harcourt Brace Jovanovich), mogu spasiti situaciju u Jugoslaviji nakon Titove smrti. To je bio najvažniji razlog zašto je Radica mislio da je izvanredno važno upravo tada tiskati Tuđmanovu knjigu, koja će jamačno iznimno doprinijeti razumijevanju europskih, a poglavito jugoslavenskih problema. ${ }^{73}$

Ubrzo nakon toga stvar se napokon rasvjetljava jer je Jovanovich poslao rezolutan odgovor. Pišući Radici pismo ekavicom, kaže da je primio tri izvje-

\footnotetext{
71 Pismo Franje Tuđmana od 2. prosinca 1978. za Velimira Sulića (poslano i Radici i Salaju). HR-HDA-1769-Radica Bogdan, kut. 24, bijela košuljica 245.

72 Pismo Franje Tuđmana od 4. siječnja 1979. za Bogdana Radicu. HR-HDA-1769-Radica Bogdan, kut. 24, bijela košuljica 245.

$73 \ldots$ and it would be significant if it would be published by You who through other books have contributed to the understanding of the thorny Yugoslav problem” [„... i bilo bi važno kad biste ga objavili Vi koji ste drugim knjigama doprinijeli razumijevanju trnovitoga jugoslavenskog problema"]. Pismo Bogdana Radice za Vladu Jovanovića (William Jovanovich), 4. rujna 1978. HR-HDA-1769-Radica Bogdan, kut. 24, bijela košuljica 245.
} 
šća o Tuđmanovim rukopisima, a i sam je nešto pročitao, pa je ostao razočaran sadržajem. Po njemu knjiga „sjedi na dvije stolice” jer nije prikazan opći primjer rezultata samoopredjeljenja naroda, a ni hrvatsko iskustvo u njegovu stvarnom značenju: „Podrazumevam da knjiga u suštini nameće hrvatsko 'rešenje' koje bi značilo ogromno previranje na Balkanu. I da je polemika a ne teorijski prikaz potkrepljen istorijskim činjenicama." ${ }^{74}$ Uglavnom, izražavajući žaljenje što su tako dugo morali čekati njegov odgovor, Jovanovich je sugerirao Radici da Tuđmanu prenese njegov interes za tiskanje eventualno njegovih memoara jer "general Tuđman nije napisao knjigu koju ja tražim”. ${ }^{75}$ Radica je na to pismo odgovorio u prilično pomirljivu tonu, štoviše govoreći da su Jovanovicheva obrazloženja o netiskanju knjige sasvim razumljiva i točna jer bi široj javnosti sigurno zanimljivije bile biografske teme memoarskoga tipa, primjerice „Uspomene generala Tuđmana” ${ }^{76}$ Radica je o novonastalim događajima pismom od 29. siječnja obavijestio Tuđmana, koji mu je odgovorio tek idućega mjeseca, očito jer pisma nije želio slati redovnom poštom. Na samom početku toga pisma Tuđman se referirao na Jovanovichevo obrazloženje o tome zašto neće tiskati njegovu knjigu, ne izražavajući pritom neko iznenađenje. ${ }^{77}$ Tuđman je izjavio Radici da je zbog svojega položaja uslijed političkoga progona nemoćan bilo što napraviti te mu postavlja više pitanja vezanih za novoga izdavača, upletenost Sulića u prijevod u Londonu, nagovještavajući mu da postoji mogućnost da više neće moći komunicirati čak ni sporadično s obzirom na okolnosti. Tuđman je još jednom istaknuo kakvo bi značenje imalo tiskanje knjige u svjetlu postojećega svjetskog interesa za jugoslavensko pitanje, jamačno misleći na tadašnje zanimanje svjetske javnosti za pogoršanje zdravlja predsjednika Tita, te brojnih nagađanja kojim će putem krenuti Jugoslavija. Pismo završava molbom u kojoj naglašava važnost da se svijet upozna

\footnotetext{
$74 \quad$ Pismo Vlade Jovanovicha (William Jovanovich) za Bogdana Radicu od 24. siječnja 1979. HR-HDA-1769-Radica Bogdan, kut. 24, bijela košuljica 245.

75 Isto. Jovanovich kaže da je njemu cilj objavljivanje jugoslavenske beletristike poput Ive Andrića, Borislava Pekića, Danila Kiša, Dobrice Ćosića, posebno ističući Milovana Đilasa, a sličnu temu o nacionalnom samoopredjeljenju obrađuje i Krsto Cviić, ali to je po njemu nešto sasvim drukčije od Tuđmanove knjige. Zanimljivo je da će Krsto Cviić petnaestak godina poslije (1993.) biti jedan od šestero potpisnika otvorenoga pisma javnosti (Krsto Cviić, Ivo Banac, Vesna Pusić, Ozren Žunec, Slavko Goldstein, Vlado Gotovac) u kojem se traži ostavka predsjednika Franje Tuđmana.

76 Na kraju pisma Radica ističe da mu još nije vraćen Tuđmanov rukopis, pa moli njegovo vraćanje. Pismo Bogdana Radice za Vladu Jovanovicha od 10. veljače 1979. HR-HDA-1769-Radica Bogdan, kut. 24, bijela košuljica 245.

77 „Od gosp. Jovanovicha nismo mogli ni očekivati drugi odgovor. On odbija rukopis koji - kako veli - 'sedi na dve stolice', a 'u suštini nameće hrvatsko rešenje', jer on na hrvatsko i jugoslavensko pitanje gleda isključivo sa stanovišta 'velikosrpskog' rješenja. Osobno sam to pretpostavljao, pa zbog toga i nisam prihvatio njegovu ponudu (1975/76) da sklopimo ugovor i da mi da predujam za ugovor." Pismo Franje Tuđmana od 2. travnja 1979. za Bogdana Radicu. HR-HDA-1769-Radica Bogdan, kut. 24, bijela košuljica 245. O tome i u: F. TUĐMAN, Osobni dnevnik, knj. II (1979. 1983.), 18.
} 
i s hrvatskim stajalištima, pri čemu on sve nade polaže u Radicu, nazvavši ga „dragi prijatelju”. ${ }^{78}$

Naravno, otvorile su se nove nedoumice, pa je Radica stupio u pregovore s novim nakladnicima nukan stalnim Tuđmanovim upozorenjima da ima sve manje vremena za realizaciju. Tako se u Radičinu pismu iz travnja 1979. može pročitati da se vratio s hodočašća u Svetoj zemlji te u uvodu daje Tuđmanu rezime situacije vezane za tiskanje knjige. Radica kaže da je upravo saznao da je pokojni Bruno Bušić ovlastio svoje prijatelje u SAD-u da oni preko odvjetnika imaju autorsko pravo na tekst (Radica piše „copyrightuju tekst”) knjige (očito je Bušić to tako shvaćao), pa su oni stupili u kontakt s nakladničkom kućom The New York Timesa, gdje je s odvjetnikom pregovarao Mate Meštrović umjesto odsutnoga Radice. Predstavnici izdavačke kuće prihvatili su ponudu tiskanja knjige uz stanovite uvjete - kako je to i inače običaj u SAD-u: traže gotov prijevod i 8.000 dolara za tiskanje i distribuciju. Taj iznos za Radicu nije problem jer će biti isplaćen iz „patriotskih izvora”, te se očekuje prijevod koji je u Londonu pokrenuo Bušić prije nego što je ubijen u atentatu. Radica se žalio Tuđmanu da ne zna tko je prevoditelj te predmnijeva da je to u rukama dr. Branka Franolića, s kojim je on o toj temi razgovarao u lipnju prošle godine (1978.), kada je bio i kod Bušića u Londonu. S druge pak strane Jakša Kušan javio je Radici da je pri kraju prijevod u koji je uložio svojih 1.500 dolara. Radica je anticipirao da Tuđman vjerojatno zna za to jer ni on, a ni Branko Salaj, koji su imali tekst knjige, nisu kontaktirali s Kušanom. Na kraju Radica piše da su Tuđmanove procjene o izdavačkoj kući Jovanovich bile točne. Jovanovich je, kako piše Radica, pod utjecajem „velikosrba”, prije svih svoje tajnice, Ličanke Drenke Willen, kojoj su ustaše ubili članove obitelji, i Vaneta Ivanovića, srbijanskoga emigranta iz Londona. Radica kaže da je vidjevši Jovanovichevo kolebanje mislio da će na nagovor Đilasa ipak pristati na suradnju, ali jamačno su im bile neprihvatljive činjenice iznesene u knjizi, prije svega da su Hrvati narod trećega reda u jednoj multinacionalnoj državi u kojoj Srbi drže sve konce vlasti, ${ }^{79}$ a pogotovo im ne bi „sjela” teza koja se stalno provlačila u knjizi: da „ne može biti nikakve dvojbe, da je nacionalno pitanje - prvorazredno pitanje europske povijesti, te da je nacionalizam pokazao veću integracionu moć od bilo kakvih drugih ideja ili ideologija". ${ }^{80}$

Tuđman je 30. travnja 1979. odgovorio na Radičino pismo te na početku naznačio da mu nije jasan pojam „copyrightuju tekst” jer on nikome nije dao

78 Pismo Franje Tuđmana od 2. travnja 1979. za Bogdana Radicu. HR-HDA-1769-Radica Bogdan, kut. 24, bijela košuljica 245.

79 Pismo Bogdana Radice od 14. travnja 1979. za Franju Tuđmana. HR-HDA-1769-Radica Bogdan, kut. 24, bijela košuljica 245.

80 F. TUĐMAN, Nacionalno pitanje u suvremenoj Europi, 194. 
autorska prava na tekst. Piše da je kopiju rukopisa poslao Bušiću jer mu je ovaj rekao da će imati brz i kvalitetan prijevod osobe koja je prevodila i Krležina djela, ali ni njemu ni njegovim prijateljima nisu predana nikakva autorska prava. Izražava i čuđenje da je Jakša Kušan uključen u prijevod jer on o tome ništa ne zna. Tuđman osobito ističe da pregovori vezani za tiskanje trebaju biti vođeni s pozornošću te da se ugovorno riješe između nakladnika i samoga autora, da mu se ovdje ne bi ponovno insinuirala kakva negativnost. ${ }^{81}$ Radica u odgovoru izražava čuđenje da je krug prijatelja Brune Bušića kod odvjetnika „copyrightirao” rukopis, a da osobno o tome nije ništa znao. Uglavnom, s obzirom na to da je propao dogovor s Jovanovichem, a prijevod Jakše Kušana iz Londona bio je na putu za SAD, Radica je izvijestio Tuđmana o aktualnim događanjima. Radi se o tome da se Radica pripremao za put u Italiju, pa je izvijestio Tuđmana da će prijevod rukopisa i pregovore s New York Timesom preuzeti Mate Meštrović, u koga Radica ima potpuno povjerenje jer će on kao izvrstan poznavatelj engleskoga pregledati prijevod i urediti s izdavačem ugovor koji će Tuđmanu osigurati vlasništvo za inozemna izdanja. Međutim, spomenuo sam da je knjiga izašla nedovršena: nema Tuđmanovih biografskih podataka, postoji priličan broj tiskarskih greški, „nisu dane karte, kazalo i što se ‘upisao' M.M. - što je pravni i politički kriminal”, ističe sâm Tuđman komentirajući „copyright” koji je glasio na Matu Meštrovića. ${ }^{82}$

U svibnju 1979., prije svojega tradicionalnog odlaska u Italiju, Radica je poslao pismo i Suliću, u kojemu mu šalje biografske i bibliografske podatke Franje Tuđmana, očekujući skori prijevod knjige iz Londona. Napominje da će prijevod predati Mati Meštroviću, navodeći mu njegovu adresu i broj telefona, jer će on nastaviti pregovore o tiskanju knjige s nakladnikom New York Timesom, a Radica će cijelo ljeto biti u Italiji. ${ }^{83} \mathrm{U}$ međuvremenu je Radica odgovorio Tuđmanu iz SAD-a prije odlaska na godišnji odmor u Italiju da ga je upravo nazvao Jakša Kušan iz Londona, koji mu je priopćio da je prijevod knjige dovršen, ali on istovremeno odbija mogućnost da se prijevod i tiskanje financiraju ili dovode u bilo kakvu vezu sa Sulićem jer bi to, prema njegovu mišljenju, samoga Tuđmana silno kompromitiralo. Zato je predložio da se za europsko i američko tržište knjiga tiska u Londonu, pa bi se time mogli isplatiti i troškovi prijevoda. Radica je smatrao da bi to bilo dobro jer bi se s jedne strane oslobodili copyrighta na koji se poziva Sulić - koga je navodno ovlastio Bušić, i krug oko njih, a zapravo nemaju takvo odobrenje ni od Radice ni autora Tuđmana. Osim toga Radica je izrazio bojazan da bi dovođenje u vezu s tim krugovima

81 Pismo Franje Tuđmana za Bogdana Radicu od 30. travnja 1979. HR-HDA-1769-Radica Bogdan, kut. 24, bijela košuljica 245 .

82 F. TUĐMAN, Osobni dnevnik, knj. II (1979. - 1983.), 128.

83 Pismo Bogdana Radice za Velimira Sulića iz New Yorka, 10. svibnja 1979. HR-HDA-1769-Radica Bogdan, kut. 24, bijela košuljica 245. 
moglo silno naškoditi Tuđmanu i kompromitirati samu knjigu, koja je čisto znanstveno djelo bez ikakvih političkih ili propagandnih intencija. Radica je završio pismo s preporukom da se Tuđman osobno angažira da Suliću objasni situaciju jer drži da bi takvu njegovu sugestiju oni pogrešno interpretirali i ne bi ga uzeli u obzir. ${ }^{84}$

Knjiga je naposljetku tiskana u New Yorku 1981. kod renomiranoga nakladnika Columbia University Press pod naslovom Nationalism in Contemporary Europe. Ne čudi oduševljenje koje Tuđman izražava u svojem dnevniku kada detaljno opisuje naslovnicu, koja je tvrdo ukoričena s plavim platnom i zlatnim natpisom, ali i razočaranje kad uviđa niz ozbiljnih propusta. Prije svega o njemu kao autoru nema nikakvih podataka, a nema ni zemljovidnih karata i dijelova teksta. Ipak je najveću konsternaciju izazvao podatak o autorskim pravima, koja su glasila na ime Matthew M. Meštrović. Tuđman se pita kako je to moguće: „Ne samo da nisam nikoga ovlastio već sam tražio da sva prava pridržavam i da nakladnik sklapa ugovor sa mnom!"85

\section{Zaključak}

Ovaj članak prati i objašnjava inicijative i poteškoće tijekom sedamdesetih godina prošloga stoljeća koje je prošao dr. Franjo Tuđman u pokušaju tiskanja svoje knjige Nacionalno pitanje u suvremenoj Europi u inozemstvu pomoću njegove korespondencije s političkom emigracijom, posebice Bogdanom Radicom, i dokumenata SDS-a, pod čijom su obradom obojica bila. Našavši se u koliziji s aktualnom komunističkom doktrinom o neizbježnom „nestanku nacija” i usred kaotičnih političkih i povijesnih zbivanja u kojima je zbog svojih stajališta i povijesnih radova dva puta bio osuđen i zatvaran (1972. i 1981.), te stjeran u izolaciju i zabranu javnoga djelovanja, Tuđman pokušava izaći iz blokade tiskanjem toga rukopisa na engleskom jeziku da bi i na taj način upoznao međunarodnu javnost s hrvatskim pitanjem u tadašnjoj Jugoslaviji. Točno predvidjevši buduće europske integracije, osnovna ideja njegova rukopisa bila je u tome da svaki narod ima pravo na vlastitu državu jer se udruživati mogu samo slobodni i jednakopravni narodi.

Glavni protagonisti inicijative tiskanja knjige su Franjo Tuđman i Bogdan Radica, dvojica istaknutih intelektualaca u tadašnjem hrvatskom korpusu. Od njihova upoznavanja u SAD-u 1966. i susreta u L'Ulivellu u Italiji do njihove korespondencije, susrećemo različite likove i protagoniste koji su, svatko na svoj način, bili involvirani u taj pothvat. Od Brune Bušića, koji je ruko-

\footnotetext{
84 Pismo Bogdana Radice od 24. svibnja 1979. za Franju Tuđmana. HR-HDA-1769-Radica Bogdan, kut. 24, bijela košuljica 245.

85 F. TUĐMAN, Osobni dnevnik, knj. II (1979. - 1983.), 109, 110.
} 
pis odnio u London na prijevod, preko Branka Salaja i Vladimira Rozijana u Švedskoj, do Mate Meštrovića i Velimira Sulića u SAD-u, možemo sagledati i kakvo je ozračje vladalo u hrvatskoj emigraciji tih godina. Zanimljiv je profil Vlade Jovanovicha (William Jovanovich), višegodišnjega poznanika Radice i Mate Meštrovića, koji je u SAD-u tiskao sve knjige Milovana Đilasa i tada bio na čelu jedne od najuglednijih američkih izdavačkih kuća - Harcourt Brace Jovanovich. On je bio u stalnom kontaktu s Radicom, a povremeno i s Tuđmanom, te je unedogled odgađao tiskanje Tuđmanove knjige. Značenje tih pisama je u tome što iz njih vidimo u kakvim je okolnostima tih godina živio angažirani hrvatski intelektualac. Naime, iako je Radica nakon rata 1945. osobno upoznao pravo lice komunističkoga terora obilazeći rodni Split, u kojem je zatekao izbezumljene sugrađane koji su mu u strahu potiho govorili o nezapamćenom teroru i da se tijekom noći obavljaju likvidacije, on ipak u svojim pismima sugerira Tuđmanu da je iznimno bitno da osoba njegova profila ostane u Hrvatskoj - osim ako ne dođe u opasnost od likvidacije - jer se sudbina Hrvatske rješava kod kuće. Iz njihove korespondencije također vidimo da su ideološki pritisci, medijska haranga i prijetnje ostali konstanta koja se i dalje događala osobama koje se nisu mirile s nepodnošljivom situacijom Hrvatske u tadašnjoj Jugoslaviji. U ondašnjim partijskim projekcijama SFRJ se mogla održati jedino kao unitaristička država koju je režim održavao represijom i progonima, poglavito u Hrvatskoj. Znajući da su pitanja nacionalne samostalnosti i federalnoga političkog uređenja strogo zabranjena za bilo kakvu javnu i znanstvenu opservaciju, Tuđman započinje rizičnu inicijativu tiskanja svoje knjige u inozemstvu ne bi li i na taj način senzibilizirao svjetsku javnost za neriješena nacionalna pitanja u Jugoslaviji.

Pisma su dojmljiva i zbog onih dijelova u kojima Tuđman otkriva svoje slutnje i skrivena duševna raspoloženja, sluteći nove progone i uhićenja jer „po svemu sudeći prvi sam na listama zatora tamnih sila, što će ga mnogi od nas teško moći izbjeći”, ali i anticipirajući rasplet jugoslavenske krize. Poglavito upadaju u oči poticaji na žurbu glede završetka pregovora o tiskanju knjige. Nekoliko je puta zamolio Radicu za žurnost ,jer ne znamo što donosi dan a što noć", čime je jasno dao na znanje da je svjestan da svojim angažmanom ne ugrožava samo svoj ugled, karijeru i egzistenciju cijele obitelji, nego je na kocki bio i njegov život. 


\section{Arhivski izvori}

HR-HDA-1561-SDS RSUP SRH: Hrvatska, Hrvatski državni arhiv, Zagreb, fond 1561, Služba državne sigurnosti Republičkog sekretarijata za unutrašnje poslove Socijalističke Republike Hrvatske.

HR-HDA-1769-Radica Bogdan: Hrvatska, Hrvatski državni arhiv, Zagreb, fond 1769, Radica Bogdan.

\section{Literatura}

ČEPULO, Dalibor. Hrvatska pravna povijest u europskom kontekstu od srednjeg vijeka do suvremenog doba. Zagreb: Pravni fakultet Sveučilišta u Zagrebu, 2012.

GAVELLA, Nikola, ur. Građansko pravo i pripadnost hrvatskog pravnog poretka kontinentalnoeuropskom pravnom krugu: teorijske osnove građanskog prava. Zagreb: Pravni fakultet Sveučilišta u Zagrebu, 2015.

KULIŠ, Danijela; TKALČEVIĆ, Mladena. „Lamer, Mirko”. U: Hrvatski biografski leksikon (on-line). Leksikografski zavod „Miroslav Krleža”. Pristup ostvaren 13. 5. 2020. https://hbl.lzmk.hr/clanak.aspx?id=11056.

MALETIĆ, Franjo, prir. Dr. Franjo Tuđman. Dosje br. 229562. Zagreb: Golden marketing - Tehnička knjiga; HVIDR-a RH, 2019.

MANOLIĆ, Josip. Špijuni i domovina. Moja borba za suverenu i socijalnu Hrvatsku. Zagreb: Golden marketing - Tehnička knjiga, 2016.

MIHALJEVIĆ, Josip. „Ustavna uređenja temeljnih prava u Hrvatskoj 1946. - 1974.” Časopis za suvremenu povijest 43 (2011), br. 1: 25-51.

New York Times (New York), 1976.

NIKOLIĆ, Dragan. „Hrvati žive svoj ‘̌vedski san””. HRT on-line, 11. 4. 2017. Pristup ostvaren 12. 4. 2020. https://vijesti.hrt.hr/383089/hrvati-zive-svoj-svedski-san.

RADICA, Bogdan. Agonija Europe: razgovori i susreti. Zagreb: Disput, 2006.

RADICA, Bogdan. Hrvatska 1945. München; Barcelona: Knjižnica Hrvatske revije, 1974.

RADICA, Bogdan. Živjeti nedoživjeti, sv. 1-2. München; Barcelona: Knjižnica Hrvatske revije, 1982-1984.

„Radica, Bogdan”. U: Hrvatska enciklopedija (on-line). Leksikografski zavod „Miroslav Krleža". Pristup ostvaren 15. 5. 2020. http://www.enciklopedija.hr/Natuknica.aspx? $\mathrm{ID}=51430$.

SADKOVICH, James J. Tuđman: prva politička biografija. Zagreb: Večernji posebni proizvodi, 2010. 
SPEHNJAK, Katarina. „Brionski plenum’ - odjeci IV. sjednice CK SKJ iz srpnja 1966. godine u hrvatskoj političkoj javnosti”. Časopis za suvremenu povijest 31 (1999), br. 3: 463-488.

SPEHNJAK, Katarina; CIPEK, Tihomir. „Disidenti, opozicija i otpor - Hrvatska i Jugoslavija 1945.-1990." Časopis za suvremenu povijest 39 (2007), br. 2: 255-297.

TUĐMAN, Ankica. Moj život s Francekom. Zagreb: Večernji list, 2006.

TUĐMAN, Franjo. Osobni dnevnik: 1973. - 1989., knj. I-III. Prir. Ankica Tuđman. Zagreb: Večernji list, 2011.

TUĐMAN, Franjo. Nacionalno pitanje u suvremenoj Europi. München; Barcelona: Knjižnica Hrvatske revije, 1981.

TUĐMAN, Franjo. O povijesti rješavanja hrvatskog pitanja i samoodređenje naroda u svijetu. Toronto: Društvo hrvatskih intelektualaca i privrednika, 1987.

TUĐMAN, Franjo. Okupacija i revolucija: dvije rasprave. Zagreb: Institut za historiju radničkog pokreta, 1963.

TUĐMAN, Franjo. Petrinjska 18. Zatvorski dnevnik iz 1972. Zagreb: Naklada Pavičić, 2003.

TUĐMAN, Franjo. Povijesna sudba naroda: izabrani tekstovi. Zagreb: Školska knjiga, 1996.

TUĐMAN, Franjo. Stvaranje socijalističke Jugoslavije:[historijska studija i pregled razvoja socijalističke revolucije i oslobodilačkog rata jugoslavenskih naroda]. Zagreb: Naprijed, 1960.

TUĐMAN, Franjo. Usudbene povjestice. Zagreb: Hrvatska sveučilišna naklada, 1995.

Večernji list (Zagreb), 2018.

VUKOVIĆ, Milan. Dr. Franjo Tuđman u sudskim dosjeima (11. siječnja 1972. - 10. lipnja 1990.). Koprivnica: Alineja, 2004. 


\section{SUMMARY}

\section{Franjo Tuđman and the Problems of Publishing the Book Nacionalno pitanje u suvremenoj Europi}

Based on sources from various fonds of the Croatian State Archives, especially the documentation of the State Security Service of the Croatian Republican Secretariat of the Interior regarding Bogdan Radica and Franjo Tuđman and the correspondence between these two intellectuals who were kept under surveillance by the Service, the author presents the circumstances surrounding the initiative to print Tuđman's book, Nacionalno pitanje u suvremenoj Europi (The National Question in Contemporary Europe), abroad. Namely, after criminal prosecutions in 1972 and 1981, Tuđman was forcibly removed from social life, pressured by the reality of Yugo-unitarism. The bold effort to publish his book despite all threats grew into an attempt to end his imposed isolation, which lasted until 1988, when he was accepted as a member of the Croatian Writers' Association, after which he began to participate at public forums and, in 1989, published the book Bespuća povijesne zbiljnosti (Horrors of War: Historical Reality and Philosophy).

Key words: Bogdan Radica; Franjo Tuđman; State Security Service (Yugoslavia); correspondence; Nacionalno pitanje u suvremenoj Europi 